\title{
The Consequences of Limiting Shareholder Litigation: Evidence from Exclusive Forum Provisions
}

\author{
Jared I. Wilson ${ }^{\mathrm{a}}$
}

August 2020

\begin{abstract}
In response to an explosion of shareholder litigation, many firms have adopted exclusive forum provisions which limit lawsuits to courts in a firm's state of incorporation. This paper examines the consequences of a required venue for shareholder litigation. Delaware-incorporated companies experience significant increases in firm value around exogenous events that confirmed the use of a specified forum. Reduced legal costs and the designation of the domicile court as the sole forum to hear shareholder claims contribute to the increase in firm value. Overall, these findings suggest that a required venue for shareholder litigation benefits firms by eliminating multi-jurisdictional lawsuits and reducing the threat of claims with little merit.
\end{abstract}

JEL Classification: G30, G34, K22, K41

Keywords: Shareholder litigation, corporate governance, exclusive forum provision

a Jared I. Wilson: Kelley School of Business, Indiana University, 801 W. Michigan Ave., BS 4036, Indianapolis, IN, 46202, email: jiw25@indiana.edu, phone: (317) 278-4715.

This is the author's manuscript of the article published in final edited form as:

Wilson, J. I. (2020). The consequences of limiting shareholder litigation: Evidence from exclusive forum provisions. Journal of Corporate Finance, 64, 101712. https://doi.org/10.1016/j.jcorpfin.2020.101712 


\section{Introduction}

Corporate governance encompasses the mechanisms through which managers and directors are incentivized to act in shareholders' interests. When management and the board fail to maximize firm value, shareholders have the ability to discipline them using litigation. Jensen (1993) suggests that directors and executives are motivated by the reputation effects of litigation. Studies, such as Ferris, Jandik, Lawless, and Makhija (2007), Krishnan, Masulis, Thomas, and Thompson (2012), and Brochet and Srinivasan (2014), provide empirical evidence of shareholder lawsuits aligning the interests of managers, directors, and shareholders. Others, however, argue that these lawsuits are ineffective in disciplining managers and directors (e.g. Helland, 2006) or that attorneys, not shareholders, realize the financial benefits of litigation (e.g. Romano, 1991). As a result, the effectiveness of shareholder litigation as a governance mechanism remains debated.

This study examines the consequences of limiting shareholders' option to discipline managers and directors using multi-jurisdictional litigation. I take advantage of the development of exclusive forum provisions and use exogenous events that validated their adoption and enforced their use as settings to address the impact of restricting shareholder corporate law claims to a firm's domicile court. An investigation of a required venue for litigation contributes to debate on the value of multi-jurisdictional shareholder suits as a disciplinary mechanism and the issue of forum shopping, which have received significant attention in the academic literature and business press.

The frequency of shareholder lawsuits claiming breaches of fiduciary duty by managers or directors in multiple courts has increased significantly in recent years. One area where this trend is apparent is in mergers. Cain and Davidoff (2013) and Cain, Fisch, Solomon, and Thomas (2018) document that while only $40 \%$ of large mergers (>\$100 million transaction value) involved litigation in 2005, over 90\% of deals did in 2012. Furthermore, of the deals litigated in 2012, more 
than $70 \%$ incurred multiple lawsuits and over $50 \%$ involved lawsuits filed in multiple forums. For example, target shareholders typically file multiple class action lawsuits in a firm's domicile court claiming that the board breached its fiduciary duty by selling the firm for an inadequate price. Moreover, shareholders often file nearly identical claims in courts outside of the state of incorporation. In most cases, these suits settle for additional disclosure about the deal and payment of plaintiffs' attorneys' fees. ${ }^{1}$ Judges on the Delaware Chancery Court have become concerned about these disclosure-only settlements and the practice of forum shopping, where attorneys search for courts that will provide the most favorable judgements and settlement of attorneys' fees. ${ }^{2}$

Many firms have responded to the increased threat of multi-jurisdictional lawsuits, especially in the context of mergers, by adopting exclusive forum provisions into corporate bylaws or charters. These provisions require that shareholder litigation must be filed in the firm's domicile court. The provisions eliminate duplicative lawsuits and litigation brought outside of the domicile court. For example, on the same day that Tesla made an offer to purchase SolarCity in June 2016, the firm amended its bylaws mandating that all future shareholder suits be filed in Delaware. ${ }^{3}$ The adoption timing was convenient given the likelihood of shareholder suits claiming a breach of fiduciary duty for what appeared to some as a bailout of one of Elon Musk's companies by another.

It is not clear whether the elimination of multi-jurisdictional shareholder lawsuits is beneficial or detrimental for shareholders. On the one hand, some shareholders claim that the provisions restrict their legal rights to choose the litigation venue. These opponents argue that the board's selection of a state such as Delaware as the required forum insulates managers and directors from

\footnotetext{
${ }^{1}$ Fisch, Griffith, and Solomon (2015), Krishnan, Solomon, and Thomas (2017), Dari-Mattiacci and Talley (2019).

2 See L. Hoffman, “Judge Makes Merger Lawsuits Disappear” The Wall Street Journal, January 11, 2016 and Cain, Fisch, Solomon, and Thomas (2018).

${ }^{3}$ See J. Wieczner, "Tesla Quietly Changed Its Bylaws to Ward Off SolarCity Shareholder Fight” The Wall Street Journal, June 23, 2016.
} 
the threat and discipline of litigation. Therefore, the managerial opportunism hypothesis suggests that a required forum for shareholder litigation weakens incentives for managers and directors to act in shareholders' best interests and has negative implications for firm value.

On the other hand, firms argue that provisions benefit shareholders by eliminating meritless suits and specifying the appropriate venue for litigation. Firms reduce legal costs by focusing on one lawsuit in one court instead of essentially identical suits in multiple courts every time a major corporate event occurs. A required forum also eliminates the risk that non-domicile courts misinterpret the incorporation state corporate law and may discourage frivolous lawsuits. The shareholder interest hypothesis suggests that a required venue for litigation has a positive impact on firm value and does not inhibit shareholders' ability to discipline managers and directors.

I begin by examining the determinants of exclusive forum provision adoption. The results suggest that firms likely to face shareholder lawsuits, either a derivative claim or a takeover-related class action suit, are more likely to adopt. These findings are consistent with an attempt to eliminate multi-forum and duplicative lawsuits by firms most likely to encounter shareholder litigation. Next, I examine the market reactions to firm announcements of exclusive forum provision adoptions. Firms likely to face shareholder litigation earn significantly positive returns around adoption. For example, companies with above median class action lawsuit (takeover) probability experience a two-day cumulative abnormal return of $0.40 \%(0.58 \%)$, which represents a \$15 (\$4) million increase in firm value for the median firm with high litigation risk. These results indicate that limiting shareholder suits to domicile courts benefits firms likely to face litigation and suggest that the costs of multi-jurisdictional lawsuits outweigh any disciplinary benefits.

I use several events related to the validity and enforcement of exclusive forum provisions as quasi-natural settings to measure the firm value effects of a required forum for shareholder suits. 
First, the Delaware Chancery Court's Boilermakers decision in 2013 validated the adoption of these provisions into corporate bylaws for Delaware-incorporated firms, which account for about $60 \%$ of all public companies. A portfolio of these firms experiences a significant return of $0.15 \%$ around the decision's announcement, suggesting that the ability to adopt a provision is positive for shareholders. Companies most likely to benefit from a provision, those with high litigation risk, experience the greatest gain in value around the decision, increasing in value by $\$ 27$ million for a median-sized firm. Second, several state courts enforced provisions of Delaware-incorporated firms by dismissing lawsuits filed outside of their specified forum. The first court to do so was the New York Supreme Court in November 2013. I find that New York headquartered firms incorporated in Delaware experience a positive return to the decision, increasing in value by $\$ 3$ million for the median-sized firm. This result indicates that multi-jurisdictional claims impose costs on shareholders. These event studies, which address concerns about endogeneity, suggest that shareholders view domicile courts as the appropriate venues for litigation.

Finally, I document one channel through which a required litigation venue increases firm value. Focusing on companies that receive a takeover offer, I detail that adopters are just as likely to face litigation, but are significantly less likely to be subject to multi-forum claims than firms without a provision. The decreased legal costs associated with merger litigation also manifest in pricing as firms with a provision obtain higher takeover premia than those without one. In a non-takeover context, I document that the rate of multi-forum and dismissed litigation is two times lower for adopters than non-adopters. These results suggest that provisions increase firm value through a reduction in legal costs associated with fewer multi-jurisdictional and potentially frivolous claims.

This study contributes to the literature by investigating the firm wealth and litigation-related implications associated with exclusive forum provisions. The evidence is important given 
disagreement over a required venue for shareholder litigation by top asset managers and pension funds. ${ }^{4}$ Prior studies focus on the determinants of provision adoption. Grundfest (2012) examines the temporal trend of provision adoption, while Romano and Sanga (2017) document that the nearuniversal adoption for IPO firms is driven by law firms and adoption post-IPO is unrelated to corporate governance. My results add to our understanding by documenting that litigation risk is a determinant of post-IPO adoption. This paper also documents the positive firm value effects associated with limiting multi-jurisdictional shareholder litigation. These results add to the prior work of Johnson, Kasznik, and Nelson (2000) who investigate the firm value effects of the Private Securities Litigation Reform Act of 1995 which sought to curb abusive federal securities litigation. My paper, however, explores the impact of changes in the state-court environment which is an important component of the shareholder litigation landscape (Thompson and Thomas, 2004).

My conclusions also complement recent papers, such as Donelson and Yust (2014) and Crane and Koch (2018), which examine the effects of changes in shareholders' ability to discipline managers using litigation. ${ }^{5}$ These studies find that decreases in litigation options available to shareholders are linked to reductions in firm value and performance. My paper documents that restricting shareholder litigation to a firm's domicile court increases firm value. This result suggests that multi-jurisdictional litigation imposes meaningful costs on firms and is not an effective governance mechanism to discipline managers and directors. Overall, I conclude that the designation of a required venue for shareholder litigation increases firm value by eliminating multi-jurisdictional lawsuits and by reducing the threat of claims with little merit.

\footnotetext{
${ }^{4}$ State Street Corporation notes in the 2018 update to its Proxy Voting and Engagement Guidelines that "SSGA generally supports exclusive forum provisions", while CalPERS states in the 2018 update to its Governance and Sustainability Principles, "companies should not attempt to restrict the venue for shareowner claims by adopting charter or bylaw provisions that seek to establish an exclusive forum."

${ }^{5}$ Other relevant studies include Cheng, Huang, Li and Lobo. (2010), Nguyen, Phan, and Sun (2018), and Ni and Yin (2018).
} 


\section{Exclusive Forum Provisions and Hypotheses}

\subsection{Exclusive Forum Provisions}

Exclusive forum provisions, adopted into either the corporate charter or bylaws, create limits on where shareholders can file state corporate law claims against the firm. Bylaw amendments can be unilaterally adopted by the board, while charter amendments must be voted on by shareholders. These provisions require that shareholder derivative actions or class action lawsuits claiming a breach of fiduciary duty by a director or officer of the firm must be filed in the domicile court (state of incorporation). For example, Chevron Corporation's bylaw provision states:

Unless the Corporation consents in writing to the selection of an alternative forum, the sole and exclusive forum for (i) any derivative action or proceeding brought on behalf of the Corporation, (ii) any action asserting a claim of breach of a fiduciary duty owed by any director, officer or other employee of the Corporation to the Corporation or the Corporation's stockholders, (iii) any action asserting a claim arising pursuant to any provision of the Delaware General Corporation Law, or (iv) any action asserting a claim governed by the internal affairs doctrine shall be a state or federal court located within the state of Delaware, in all cases subject to the court's having personal jurisdiction over the indispensable parties named as defendants.

Exclusive forum provisions eliminate multi-jurisdictional litigation. In particular, they target merger-related suits given the multi-forum nature of these claims (Cain et al., 2018).

\subsection{Boilermakers Decision}

In February 2012, shareholders of twelve Delaware-incorporated firms with existing bylaw provisions sued each firm's board in the Delaware Chancery Court claiming that directors lacked the power to adopt such provisions into a firm's bylaws without shareholder consent. All but two of the sued firms repealed their existing provisions, whereas Chevron Corporation and FedEx Corporation did not, instead deciding to litigate. On June 25, 2013, the Delaware Chancery Court ruled for both companies in the Boilermakers decision. ${ }^{6}$ Following this decision, boards of

\footnotetext{
${ }^{6}$ Boilermakers Local 154 Retirement Fund et al. v. Chevron Corp. et al., No. 7220-CS; IClub Investment Partnership v. FedEx Corp. et al., No. 7238-CS, 2013 WL 3191981 (Delaware Chancery, June 25, 2013).
} 
Delaware-incorporated firms have the authority to adopt a provision into firm bylaws without shareholder consent at any time, similar to the threat of a "shadow" poison pill (Coates, 2000). The Delaware Chancery Court, however, did not rule on the enforceability of these provisions.

\subsection{Enforcement of Exclusive Forum Provisions}

The question of enforceability was left to other state courts. The first such decision occurred in the New York Supreme Court on November 4, 2013. ${ }^{7}$ In HEMG Inc. v. Aspen University, the court enforced Aspen Group, Inc.'s exclusive forum provision by dismissing six derivative suits filed in New York by shareholders against the Delaware-incorporated firm. Two other state courts made similar decisions subsequently. The Illinois Chancery Court of Cook County dismissed claims brought in Illinois challenging a merger and enforced Beam, Inc.'s provision on March 5, 2014. ${ }^{8}$ The court held that it was reasonable for a firm incorporated in Delaware and headquartered in Illinois to limit legal expenses by restricting litigation to a required venue. The Superior Court of California’s decision on May 14, 2014 enforced Safeway, Inc.'s provision by dismissing claims filed in California against the Delaware-incorporated firm in connection with a proposed merger. ${ }^{9}$

\subsection{Shareholder Interest Hypothesis}

The shareholder interest hypothesis contends that exclusive forum provisions benefit shareholders by eliminating multi-forum lawsuits. This is important because litigation consumes significant time for managers and directors and can be costly for firms (e.g. Bizjak and Coles, 1995, Field, Lowry, and Shu, 2005). ${ }^{10}$ Some prior literature contends that litigation financially

\footnotetext{
${ }^{7}$ HEMG Inc. v. Aspen Univ., No. 650457/13, 2013 WL 5958388 (N.Y. Sup. Ct., Nov. 4, 2013).

${ }^{8}$ Miller v. Beam Inc., No. 2014 CH 00932 (Ill. Cir. Ct., March 5, 2014).

${ }^{9}$ Groen v. Safeway Inc., No. RG14716641 (California Superior Court, Alameda County, May 14, 2014). Courts is Louisiana, Oregon, and Ohio also enforced exclusive forum provisions: Genoud v. Edgen Group Inc., No. 625,244 (19th Jud. Dist. Ct., East Baton Rouge, La., Jan. 17, 2014), Roberts v. TriQuint SemiConductor, Inc., No. 1402-02441 (Or. Cir. Ct., Aug. 14, 2014), North v. McNamara, No. 1:13-cv-833 (S.D. Ohio, Sept. 19, 2014).

${ }^{10}$ In the first two years of my sample (2010 \& 2011), Cain and Davidoff (2013) report an average number of shareholder suits per merger transaction of 4.7 (5.0) and average attorneys' fees of \$1,263,000 (\$1,430,000) per deal.
} 
benefits lawyers rather than shareholders (Bebchuk, 1996). In addition, evidence by Romano and Sanga (2017) that post-IPO provision adopters have similar governance as non-adopters is suggestive that provisions are unlikely to harm shareholders. Specifying the domicile court as the sole venue may also benefit shareholders by eliminating any home court advantage for managers and directors in the headquarters' state where there may be sympathies for the local company. ${ }^{11}$

In addition to legal costs, managers and directors face reputation costs associated with shareholder litigation. ${ }^{12}$ The fear of reputation penalties may discourage some individuals from serving as directors or cause incumbent directors to be risk averse, reducing board effectiveness (Black, Cheffins, and Klausner, 2006). Armour, Black, and Cheffins (2012) suggest that Delaware judges apply plaintiff attorney fee scrutiny to encourage what the judges perceive as valid cases and discourage frivolous cases in Delaware. Given that firms overwhelmingly choose Delaware as their required forum, this may limit meritless claims. The shareholder interest hypothesis makes two empirical predictions. First, firms that specify a required venue should experience positive returns around adoption announcements. Second, firms affected by the decisions that validated and enforced provisions should increase in value around these announcements.

\subsection{Managerial Opportunism Hypothesis}

The managerial opportunism hypothesis suggests that a required forum for litigation harms shareholders by restricting their choice of venue and discouraging discipline of managers and directors using multi-forum lawsuits. ${ }^{13}$ Armour, Black, and Cheffins (2012) provide evidence that shareholder lawsuits are increasingly brought outside of Delaware. This suggests that shareholders

\footnotetext{
${ }^{11}$ See D. Marcus, “Investor case over Wal-Mart bribes hangs on judge’s advice” Reuters News, November $13,2015$.

${ }^{12}$ Hanley and Hoberg (2012) suggest that firms have strong incentives to avoid reputational losses related to litigation.

${ }^{13}$ In general, the Council of Institutional Investors and proxy advisory firms Institutional Shareholder Services, Inc. (ISS) and Glass, Lewis \& Co. oppose provision adoption without a shareholder vote. ISS and Glass Lewis suggest that the provisions may negatively impact shareholders by removing their choice of venue. Glass Lewis recommends voting against the governance committee chair of any firm that has adopted a provision without shareholder approval.
} 
and their lawyers find the benefit of filing suit in Delaware to be lower than in other states. Several studies suggest that Delaware corporate law may cater towards managerial interests (e.g. Cary, 1974, Bebchuk, 1992). Therefore, provisions may act to increase the job security of incumbent management and directors through more favorable outcomes or by discouraging suits filed in a forum of the board's choice. Prior literature finds that settlements of derivative litigation include reforms to governance practices (Ferris et al., 2007, Erickson, 2010). If provisions deter litigation, the incentive alignment between shareholders, directors, and managers may be weakened.

Prior studies provide evidence that the fear of lawsuits can motivate directors to act in the interests of shareholders (Fama and Jensen, 1983, Bhagat, Brickley, and Coles, 1987, Fich and Shivdasani, 2007, Karpoff, Lee, and Martin, 2008). However, if provisions reduce this threat, the risk of reputation loss is reduced. Previous studies related to director and officer (D\&O) insurance and indemnification provisions suggest mechanisms that shield these agents from the discipline of litigation may create unintended moral hazard (Chalmers, Dann, and Harford, 2002, Bradley and Chen, 2011, Lin, Officer, and Zou, 2011). This suggests negative outcomes for similar governance mechanisms that may shield directors and officers from shareholder litigation. The managerial opportunism hypothesis predicts that firms adopting a provision and those affected by the Boilermakers and enforcement decisions should decrease in value around these announcements.

\section{Research Design and Descriptive Statistics}

The initial sample to investigate the shareholder wealth effects of a required venue for litigation is drawn from the Compustat database. I begin with 78,527 firm-year observations from fiscal year 2009 to 2015. This sample is merged with the CRSP database for stock returns, the Thomson Reuters Institutional Ownership database for institutional ownership, Thomson/SDC U.S. Merger and Acquisition database (SDC) for acquisition data, Execucomp for CEO characteristics, and 
Institutional Shareholder Services (ISS) and Management Diagnostic’s BoardEx for governance data. After excluding firm-years with missing values for stock returns, assets, and institutional ownership, the final sample consists of 25,544 firm-year observations for 5,078 unique firms.

Firms with exclusive forum provisions are identified in two ways. First, I conduct a Factiva search using the keywords 'exclusive forum' and 'current report' to search for public companies that have amended their charter or bylaws to include a provision (midstream adopters) which yields 8-Ks announcing the amendments. Information related to the adoption is collected from these 8Ks and other documents (i.e. DEF 14A). Second, I search S-1 (IPO) filings for firms that went public between 2010 and 2015 with a provision. ${ }^{14}$ The final sample is restricted to 538 midstream adopters (2,259 firm-years) and 244 IPO adopters (657 firm-years). The subsequent analysis related to adoption determinants and firm value effects are limited to only midstream adopters, while tests on the market reaction to the Boilermakers and enforcement decisions, and the postadoption litigation and takeover premia outcomes include both midstream and IPO adopters.

There are three sets of variables along which the determinants of provision adoption and firm value effects may vary. First, following Kim and Skinner (2012) and Bourveau, Lou, and Wang (2018), I estimate three ex-ante shareholder litigation risk measures as the fitted values from panel regressions modeling the probability of a (1) derivative lawsuit (derivative lawsuit probability), (2) class action lawsuit (class action lawsuit probability), and (3) derivative or class action lawsuit (shareholder lawsuit probability). I hand collect information on derivative claims and class actions filed in state courts from company $10 \mathrm{~K}$ reports using the Wharton Research Data Services (WRDS) SEC Analytics Suite Filings Search. ${ }^{15}$ I supplement this with searches of the Delaware

\footnotetext{
${ }^{14}$ In addition, I consult the lists of exclusive forum provision adopters provided in Allen (2012) and Allen (2014).

${ }^{15}$ I use the following keywords to search for lawsuits: "derivative lawsuit”, "derivative action”, "derivative litigation”, "derivative suit”, "derivative compliant”, "shareholder class action”, "stockholder class action”, "purported class action", and "putative class action". Variable definitions and estimation results are included in Appendix B.
} 
Chancery Court using Bloomberg Law. I also use an indicator variable, equal to one for firms in high litigation risk industries as in Francis, Philbrick and Schipper (1994), as an additional proxy.

The second set is takeover risk, which proxies for the likelihood that a firm is subject to multiforum litigation. ${ }^{16}$ Cain et al. (2018) report that merger lawsuits include a significant amount of multi-jurisdictional litigation, which these provisions specifically target. I estimate ex-ante takeover probability from a model following Cremers, Nair, and John (2009). Romano and Sanga (2017) suggest that adopters have higher-quality governance than non-adopters. ${ }^{17}$ Therefore, I also consider the effect of governance features commonly associated with agency conflicts including board independence, board co-option (Coles, Daniel and Naveen, 2014), board busyness (Fich and Shivdasani, 2006), CEO-Chair duality, classified board, and institutional ownership.

To mitigate endogeneity concerns inherent in the tests described above, I use the Boilermakers decision and three court enforcement decisions described in Sections 2.2 and 2.3 as quasi-natural settings to measure the value effects of a required forum for litigation. These events were not anticipated and were exogenous to confounding effects related to firm-specific provision adoption. ${ }^{18}$ Schwert (1981) suggests that stock price changes following an announcement can be informative about the market's valuation of the decision, but recommends forming portfolios to reduce the cross-sectional correlation between stocks. I follow the methodology of Cai and Walkling (2011) and Akyol, Lim and Verwijmeren (2012) to form equal-weighted portfolios based on the likelihood that firms are affected by the decisions. Consistent with Li, Pincus, and Rego (2008) and Akyol et al. (2012), I examine cumulative abnormal returns (CARs) in a two-day [0,

\footnotetext{
${ }^{16}$ Thomas and Thompson (2004) report that merger-related shareholder lawsuits are the dominant form of corporate litigation representing 80\% of breach of fiduciary duty claims in 1999 and 2000 in the Delaware Chancery Court.

${ }^{17}$ Prior literature, such as Brickley, Coles and Terry (1994), suggests that the firm value implications associated with the adoption of internal governance mechanisms vary by existing firm governance structures.

${ }^{18}$ I conduct a Factiva search in the year prior to each decision for outcome-related news. I also search memos by Tier 1 law firms in corporate/M\&A law (U.S. News and World Report). The searches do not yield any results. However, to the extent that unobservable events signaled their outcomes, it will bias against finding significant results.
} 
+1 ] window around each event. ${ }^{19}$ I use the Fama-French-Carhart four factor model as the benchmark to measure two-day CARs around the event dates. I estimate the following regressions:

$$
R_{p, t}=\alpha+\beta_{1} R_{m, t}+\beta_{2} S M B_{t}+\beta_{3} H M L_{t}+\beta_{4} U M D_{t}+\beta_{5} \text { Event }_{t}+e_{t}
$$

where $R_{p}$ is the portfolio return, $R_{m}$ is the market return, SMB is the size factor, HML is the bookto-market factor, and UMD is the momentum factor, all at date $t$. The dummy variable Event $t_{t}$ equals one for each trading day in the two-day $[0,+1]$ window around each event. The estimated average daily abnormal return during the event window is captured by the $\beta_{5}$ coefficient.

Table 1 provides characteristics for the 782 firms with a provision. ${ }^{20}$ Panel A reports that $69 \%$ (31\%) are midstream (IPO) adopters, that typically add the provision to the corporate bylaws (charter). Of the 541 (241) firms with a bylaw (charter) provision, 93\% (82\%) adopted without shareholder approval. In unreported results, I find that 80 firms introduced management proposals to adopt a provision. Of these, $86 \%$ received shareholder approval. ${ }^{21}$ Over half of all provisions were adopted with other bylaw or charter amendments. Finally, 80\% of firms adopted following the Boilermakers decision suggesting that this decision provided clarity on the validity of adoption.

Panel B of Table 1 reports the temporal distribution of adoptions. The low adoption rate in 2012 is attributed to firms' reluctance to adopt until the resolution of the Boilermakers decision. Once resolved, there was an increase in adoption rates in 2013. Panel C describes the industry distribution of provisions by Fama-French 12 industry classifications. Adoption is not concentrated in any one industry; business equipment (21\%), healthcare (19\%), and financials (12\%) are the most well represented ones. Panel D of Table 1 details the states selected as

\footnotetext{
${ }^{19}$ The short event window is used to reduce the possibility of noise from other surrounding events affecting the return results. I also find consistent results using a longer four-day $[0,+3]$ window around each event.

${ }^{20}$ Romano and Sanga (2017) analyze a sample of 746 adopting firms through December 31, 2014. While my sample extends through December 31, 2015, the similar number of adopting firms is due to data restrictions in this study.

${ }^{21}$ It is possible that the high approval rate could be the result of firms bundling multiple bylaw or charter amendments into one vote, although I find that $94 \%$ of the proposals solely address the addition of an exclusive forum provision.
} 
exclusive forums and incorporation (headquarters) states. Firms overwhelmingly choose their state of incorporation as their exclusive forum (98\%) and the vast majority of these adopters are incorporated in Delaware (89\%). A small percentage of firms (1.8\%) choose their state of headquarters as their exclusive forum, however, most of these are incorporated in Delaware (79\%). Grundfest (2012) and Romano and Sanga (2017) also construct samples of adopters and find similar distributions of IPO/non-IPO, charter/bylaw and pre-/post-Boilermakers decision adopters.

\section{Empirical Results}

\subsection{Determinants of Exclusive Forum Provision Adoption}

Table 2 presents univariate comparisons of provision adoption firm-years (526) and firm-years for non-adopting firms $(23,285)$ from 2009 to 2015. The results in Panel A indicate that adopters have a higher likelihood of receiving derivative and class action lawsuits and are more likely to be in a high litigation risk industry. Panel B of Table 2 reports that adopters are larger, have higher operating performance, higher Tobin's Q, more free cash flow, and lower stock return volatility than non-adopters. Provision adopters are also more likely to be incorporated in Delaware and a state that differs from the state of headquarters. This result is consistent with an attempt to eliminate duplicative multi-forum litigation that may be filed in the state of headquarters and incorporation. The results of Panel C suggest that adopters have more independent boards and higher institutional ownership. This is consistent with Pukthuanthong, Turtle, Walker, and Wang (2017), who find that institutional ownership is positively related to shareholder suits.

Table 3 summarizes the results of logistic regressions modeling the likelihood of provision adoption as a function of lawsuit probability, firm attributes, and governance. The regressions also include year and industry fixed effects to control for industry spillover effects of litigation (Gande and Lewis, 2009). Panel A includes all firm-years and Panel B (C) includes a sub-sample with 
available governance measures (information on directors' other directorships). The dependent variable is equal to one if the firm adopted in that fiscal year. ${ }^{22}$ Standardized coefficients are reported which relate the effect on the likelihood of adoption for a one standard deviation change in a continuous variable, or a change from 0 to 1 for an indicator variable. Coefficient $p$-values based on bootstrapped standard errors to account for the generated regressors (standard errors clustered by industry) in Models 1-3 and 5 (4) are reported in parentheses (Pagan, 1984).

After controlling for firm and industry factors, Models 1-4 of Panel A indicate that adoption is positively related to the threat of litigation. For example, with a one standard deviation increase in class action lawsuit risk, the likelihood of adoption increases by 6.6 percentage points, representing more than a three-fold increase in the unconditional rate of adoption (2.0\%). Adopters are also larger, have lower stock performance, higher $R \& D$ expenditures, and more free cash flow. ${ }^{23}$ Even after controlling for firm attributes, adopters are more likely to be incorporated in a state different from their headquarters' state to eliminate multi-forum suits. ${ }^{24}$ Model 5 details a positive relation between adoption and takeover probability. For adopters that receive a takeover offer, the median number of days between adoption and the offer is three days. This provides further evidence that the elimination of multi-forum lawsuits is a significant motive for adoption.

The regressions in Panel B of Table 3 control for internal and external measures of governance. Firm controls are unreported for brevity but have the same sign and significance as in Panel A. After controlling for firm governance, provision adopters remain more likely to be subject to shareholder litigation. Other than board independence, firm governance mechanisms do not have a significant impact on provisions adoption, consistent with Romano and Sanga (2017).

\footnotetext{
${ }^{22}$ In unreported results, I remove all observations of adopters in the years following adoption and obtain similar results.

${ }^{23}$ This result is consistent with Arena and Julio (2015) who find that litigation risk is related to higher cash holdings.

${ }^{24}$ Results are robust to replacing the Different Inc./HQ indicator with an indicator for Delaware incorporation.
} 
Despite the significance of shareholder lawsuit and takeover probabilities as determinants of adoption, there is a group of firms that adopt provisions with low likelihoods. Bouwman (2011) suggests that governance practices, such as board size, are transferred from one firm to another through overlapping directors. It is possible that provision adoption is also influenced by the governance practices of a director's other boards. Following Bouwman (2011), I construct a weighted average of adoption at firms with overlapping directors (Outside Directorship Adoption). For each director, I calculate the rate of provision adoption at the director's other boards weighted by their number of outside directorships. This weighted adoption rate is then averaged over each firms' board and scaled by board size. Models 1-5 in Panel C of Table 3 document a significantly positive relation between adoption at one firm and adoption rates at directors' other boards. Even after controlling for overlapping director adoption, lawsuit and takeover probability have a significant effect on adoption. Models 6 and 7 find that the impact of overlapping director governance practices is concentrated in firms with lower lawsuit risk, suggesting that this is a distinct determinant of adoption. Overall, results from Table 3 add to our understanding of provision adoption by documenting that firms with high litigation risk are more likely to adopt.

\subsection{Market Reaction to Exclusive Forum Provision Adoption}

To examine the market reaction to provision adoption, I construct a sample of 460 companies that adopt a provision into either their corporate charter or bylaws in which I can observe a cumulative abnormal return around this announcement. This sample of announcements excludes any with a takeover announcement within the $[-3,+3]$ window surrounding adoption. Table 4 reports average Fama-French-Carhart four-factor adjusted two-day $[0,+1]$ cumulative abnormal returns around the filing dates of the 8-K announcing the amendments to the charter or bylaws. ${ }^{25}$

\footnotetext{
${ }^{25}$ Announcement returns are winsorized at the $1 \%$ and $99 \%$ levels. Results are robust to using a $[0,+3]$ day window or using market-adjusted returns.
} 
Panel A reports that the full sample average adoption announcement return is positive $0.19 \%$, but does not statistically differ from zero. It is possible that an insignificant average return for the full sample indicates a tradeoff between the benefits and costs to shareholders associated with provision adoption. This tradeoff may depend on firm litigation risk or governance structure. Therefore, I compare announcement returns for firms sorted into high and low sub-samples based on full sample median firm attributes measured as of the fiscal year end prior to the announcement.

Panel B of Table 4 focuses on shareholder litigation risk. Firms with above median derivative lawsuit probability experience a positive $0.23 \%$ announcement return, a $\$ 9$ million increase in value for the median-sized firm. ${ }^{26}$ Adopters with high class action risk experience a significant $0.40 \%$ average announcement return. In addition, the average market reaction for firms in high litigation risk industries is $0.61 \%$. Results in Panel C indicate that, on average, adoption firms with high takeover risk experience significantly positive announcement returns of $0.57 \%$ (p-value $=0.008$ ). This represents a $\$ 4$ million increase in value for the median-sized firm in this group. These results suggest that provisions are especially valuable to firms that are likely to be subject to multi-forum claims. Tests in Section 4.4 explore the channels of the increases in firm value.

It is possible that provision adoption, which eliminates multi-forum litigation prevalent in mergers, may signal a future takeover offer. To address this concern, I examine adopters in which a future takeover bid may be more anticipated. Cai, Song, and Walkling (2011) document that bids following a lull in industry takeover activity are less anticipated than subsequent bids in that industry. Therefore, I focus on adoptions in industries with high prior takeover activity, which should better reflect the impact of the provision and not an upcoming bid. Panel D of Table 4 reports that the average return for firms with above median takeover probability and industry

\footnotetext{
${ }^{26}$ The change in market value is calculated as the median market value of firms with above median derivative lawsuit probability ( $\$ 3,701$ million) multiplied by the average announcement return for these firms.
} 
takeover activity is a statistically significant $0.80 \%$. While this test is unable to fully rule out the effects of anticipation, subsequent tests are free from these concerns and draw similar conclusions.

While adoption at a director's other directorships is a significant factor in adoption, it does not have an effect on announcement returns (Panel E). Similarly, there is no evidence that firms incorporated and headquartered in different states have returns that differ from firms incorporated and headquartered in the same state (Panel F). The returns for firms incorporated in Delaware are no different from firms incorporated elsewhere. ${ }^{27}$ This result is inconsistent with boards choosing Delaware as an exclusive forum to insulate themselves from litigation. Panel G reports that the average return for bylaw (charter) adopters is $0.14 \%(0.70 \%)$. The difference between these returns is not statistically different, even though charter amendments require shareholder approval.

Panel $\mathrm{H}$ of Table 4 sorts adoption returns based on firm governance. Adopters with more independent boards experience significantly positive returns suggesting that firms with more independent monitoring benefit from a provision. Other than independence, there is little evidence that returns vary by governance. This includes firms with high co-option, busy directors, or those with a CEO-Chair or classified board that may be perceived as having weaker governance (e.g. Bebchuk and Cohen, 2005). These results suggest that governance does not play a role in the value associated with provisions and provide no evidence for the managerial opportunism hypothesis.

It is possible that the announcement of other corporate events in conjunction with provision adoption could influence the results in Table 4. I identify 113 (60) adoptions that coincide with another event (bylaw change) within a $[-3,+3]$ window. $^{28}$ In untabulated results, I exclude these adoptions and find consistent results. Collectively, the results in Table 4 indicate that that there

\footnotetext{
${ }^{27}$ Of the 67 non-Delaware incorporated adopters that chose their state of incorporation as their exclusive forum, the most well-represented states include Maryland (10), North Carolina (6), Indiana (5), Pennsylvania (5) and Nevada (5). 28 These other corporate events include earnings announcements, annual shareholder meetings, dividend announcements, stock repurchase announcements, director/officer changes, and filings of litigation.
} 
are meaningful costs associated with multi-jurisdictional shareholder suits and that firms likely to be subject to litigation benefit from the designation of a required venue for shareholder litigation.

\subsection{Market Reaction to Boilermakers Decision}

The Boilermakers decision on June 25, 2013 provides a quasi-natural experiment around which to further study the firm value effects associated with exclusive forum provisions. The sample examined includes all firms incorporated in Delaware with available stock return data (2,188 firms). This test is restricted to Delaware incorporated firms given that the decision was made by the Delaware Chancery Court and was solely applicable to these firms. Equation (1) is used to estimate the abnormal returns to portfolios in the two-day event window around the decision.

Overall, the results confirm the positive firm value effects associated with limiting shareholder lawsuits to a required forum. All Delaware-incorporated firms are affected by this decision given that companies either already have a provision in place or have the ability to unilaterally adopt one without shareholder approval at any time, much like a "shadow" poison pill. Panel A of Table 5 reports that the portfolio return of all Delaware-incorporated firms around the decision is a significantly positive $0.148 \%$ ( $(\mathrm{t}$-stat $=4.04)$. It is possible, however, that some companies benefit more from this decision than others. Panel B reports that the portfolio of firms that had adopted a bylaw provision prior to the decision experiences a positive $0.41 \%$ return $(\mathrm{t}$-stat $=1.51)$. While this result is not statistically different from zero, the positive return effect for bylaw adopters is concentrated in firms with high shareholder lawsuit probability (above full sample median) which experience a significantly positive return of $0.87 \%(t-s t a t=4.66) .{ }^{29}$ Firms that had not adopted a provision prior to the decision experience a significant $0.13 \%$ return $(\mathrm{t}$-stat $=3.67)$ which suggests that the market values the ability to adopt a provision. ${ }^{30}$ In untabulated results, I find that the

\footnotetext{
${ }^{29}$ I find similar results if above median shareholder derivative or class action lawsuit probability is used instead.

${ }^{30}$ Results are robust to including charter provision adopters in the non-adopter portfolio.
} 
portfolio of 971 of these firms with high lawsuit probability experiences a $0.42 \%$ (t-stat $=3.24)$ return indicating that these firms are most likely to benefit from eliminating multi-forum suits. ${ }^{31}$

Panel C of Table 5 sorts all firms based on shareholder lawsuit probability. ${ }^{32}$ The results indicate that the returns around the decision are positively related to litigation risk. Firms in the top quartile of litigation risk experience a return of $0.67 \%$ which is significant at the $1 \%$ level and translates to a gain of $\$ 27$ million for the median-sized firm in this portfolio. ${ }^{33}$ While the return for the portfolio with the lowest litigation risk is negative, this is the only evidence presented that could be consistent with the managerial opportunism hypothesis and the negative effect is several magnitudes smaller than the positive one for firms likely to face litigation. It is possible that litigation risk captures both a high risk of frivolous lawsuits or poor governance. Therefore, in untabulated results, I sort firms with the highest litigation risk into portfolios based on the likelihood they will face frivolous lawsuits following Crane and Koch (2018). ${ }^{34}$ I find that for firms with high litigation risk, both those with high and low likelihoods of facing frivolous lawsuits experience positive returns around the decision. Collectively, the findings in Table 5 indicate that the ability to specify a required venue for shareholder claims is viewed positively by shareholders.

\subsection{Market Reaction to Enforcement Decisions}

Decisions by state courts to enforce exclusive forum provisions provide a second quasi-natural setting to examine the firm value effects of a required forum for litigation. Table 6 reports the return around the New York, Illinois, and California decisions for the sample of firms affected by each one (i.e. Delaware incorporated firms with New York headquarters). The portfolio of 210

\footnotetext{
${ }^{31}$ In unreported results, I find that the market reaction to the Boilermakers decision does not vary by firm governance.

${ }^{32}$ Results are robust to sorting portfolios on derivative or class action lawsuit probability and to excluding adopters.

33 Dollar values are the portfolio CAR multiplied by the median market capitalization of portfolio firms.

${ }^{34}$ Crane and Koch (2018) use high return volatility, negatively skewed stock returns, low minimum returns, California headquarters, and high tech industries to proxy for likely exposure to frivolous litigation.
} 
New York headquartered firms incorporated in Delaware experiences a return of $0.53 \%$ around the New York decision which is statistically significant at the $1 \%$ level. The gain in firm value for these firms equals \$3 million dollars for the median-sized firm in the portfolio. This result suggests that one channel through which a required forum for litigation may create value is the dismissal of duplicative suits filed outside of the domicile court. The results around the Illinois decision provide additional evidence that the enforcement of a designated forum for litigation is positive for firm value. The 127 Illinois headquartered firms incorporated in Delaware examined experience a statistically significant return of $0.39 \%(t-s t a t=5.21)$. While the positive portfolio return around the California decision is not statistically significant, this result likely reflects that the decision was to some extent already expected. Overall, the findings in Tables 6 confirm the conclusions of the Boilermakers event study in a separate exogenous setting and suggest that multijurisdictional shareholder litigation imposes significant costs on firms.

\subsection{Channels of Firm Value Increases for Provision Adopters}

There are several channels through which a required venue for shareholder litigation may increase firm value. First, the elimination of multi-forum litigation may decrease direct legal costs such as attorneys' fees, settlement amounts, D\&O insurance premiums, and manager and director time diverted away from their main responsibilities. Second, a reduction in multi-jurisdictional suits may decrease the reputation costs faced by managers and directors. Third, a single venue for litigation eliminates two possible outcomes in non-domicile courts: the misinterpretation of the domicile court's corporate law and a home court advantage for the firm in the headquarters' state where there may be sympathies for a local company. Not all of these reduced or eliminated costs are directly measurable. In this section, however, I examine a number of settings that capture observable channels of the firm value increases related to reductions in legal costs. 
Given the time intensive process of lawsuit data collection, I conduct two tests on propensityscore matched samples of provision adopters and non-adopters. The propensity-score models are based on Model 1 in Panel A of Table 3. The first test focuses on takeover targets given the high risk of receiving multi-jurisdictional shareholder suits around these events. Consistent with Thomas and Thomson (2004), these lawsuits are class action claims and name the target firm, target board, and acquiring company as defendants. Each adopter that receives a takeover offer following provision adoption is matched to a non-adopting takeover target without replacement using the closest propensity score. This sample includes 83 adopters and 83 matched non-adopters.

Table 7 documents that adopters are no more or less likely to be subject to a lawsuit than nonadopters. This suggests that limiting litigation to the domicile court does not deter merger litigation in general. However, adopters are subject to significantly fewer lawsuits in fewer forums. Provision (non-)adopters are subject to 3.74 (4.75) lawsuits filed in 1.22 (1.47) forums. Even though adopters are subject to claims in multiple forums, these suits are either settled or dismissed. Adopters are more likely to be subject to litigation within only their state of incorporation rather than subject to multi-forum lawsuits (state of incorporation and headquarters). This is consistent with the aim to funnel lawsuits to the domicile court that has expertise in applying the corporate law governing that firm. One alternative explanation for adopters receiving less multi-forum litigation is that plaintiffs shift their lawsuits to federal courts instead of the required venue. Cain, Fisch, Solomon, and Thomas (2019) document a significant shift in merger litigation from state to federal courts from 2014 to 2018. I find that while the rate of suits filed in federal court is higher for adopters than non-adopters (19.3\% vs. 15.7\%), the rates are not statistically different.

Table 7 also explores outcomes for 589 of the takeover-related lawsuits (93\% of sample). I find that lawsuits filed against targets with a provision are more likely to settle for additional 
disclosure about the deal and payment of plaintiffs' attorneys' fees (disclosure-only settlement), but there is no difference in the dismissal rates of the lawsuits between the two groups. I also contrast the outcomes of lawsuits filed within an adopter's exclusive forum to those filed outside of that forum and find no significant differences in outcomes between the two. These results suggest that exclusive forum provisions do not deter lawsuits in the context of takeovers, but do reduce duplicative litigation by eliminating multi-forum suits and thus decrease legal costs.

The second test to address lawsuit consequences focuses on derivative and class action claims in a non-takeover context. A sample of adopters is matched with up to three non-adopting firms with the closest propensity score, in the same year and industry. This sample includes 495 (890) adopter (firm-years) and 1,033 (2,730) non-adopting firms (firm-years) that are followed for up to three years. Panel A of Table 8 details that the average rate of litigation for adopters is $3.48 \%$ in a given firm-year which is not significantly different from that of non-adopters. The rate of multiforum and dismissed litigation, however, does differ significantly. While non-adopters are subject to multi-forum lawsuits, adopters are not. In addition, the rate of dismissed litigation is more than two times lower for adopters than non-adopters. Following Dyck, Morse, and Zingales (2010) and Kempf and Spalt (2018), I characterize dismissed lawsuits as lower quality litigation. This result suggests that a required venue for litigation reduces the risk of claims with little or no legal merit. One possible alternative explanation for provision adopters receiving less multi-forum litigation and fewer lower quality suits is that shareholders shift their lawsuits to federal courts rather than file in the required venue. Using the AuditAnalytics database, however, I find that shareholders are less likely to file suit against adopters in federal courts than non-adopting firms. If provisions reduce the disciplinary threat faced by firms, managers may have an opportunity to change firm governance. I test whether a firm's governance changes following adoption using the 
methodology of Appel (2019) and find no significant changes to board independence, co-option, CEO-chair duality, blockholder ownership, classified board, or CEO cash compensation.

Panel B of Table 8 confirms the results of Panel A by focusing on the lawsuit level. Of the non-takeover lawsuits filed against adopters, none were filed outside of the company's domicile court, while almost $8 \%$ of lawsuits filed against non-adopters were multi-jurisdictional. In addition, almost $40 \%$ of suits filed against non-adopting firms were dismissed compared to only $15 \%$ for firms with a provision, representing a statistically and economically significant difference. Of the dismissed claims filed against non-adopting firms incorporated in Delaware, 88\% are filed in the firm's headquarters' state (not Delaware). This result suggests that the required forum of Delaware reduces what may be litigation with little or no legal merit against provision adopters.

One potential outcome of the reduction in legal costs documented in Tables 7 could be increased takeover premia. I examine a sample of 1,011 takeover offers including 100 (911) firms with(out) an exclusive forum provision at the deal announcement. I address the endogenous selection of provision adoption by using a two-stage least squares (2SLS) instrumental variable approach. A valid instrument for the endogenous variable (provision adopter) must meet two conditions: the relevance and exclusion restrictions. I use a geographic-based instrument that accounts for whether the firm is incorporated in Delaware. This instrument is correlated with provision adoption given the results of Tables 2 and 3, thus meeting the relevance condition. The instrument also reasonably meets the exclusion restriction as the decision to incorporate in a particular state is determined early in a firm's life and is unlikely to be related to takeover premia.

Table 9 summarizes the results of the two-stage least squares analysis. The first stage OLS model regresses the endogenous indicator variable of an exclusive forum provision on the instrument and all controls variables. In the second stage, the endogenous variable (provision 
adopter) is replaced with the predicted values from the first stage model, which capture the probability that a firm has a provision at the time of the takeover offer. Takeover premia is then regressed on the instrumented endogenous variables and the same controls from the first stage.

Model 1 of Table 9 reports the first stage OLS model estimating the likelihood that a firm has a provision at the time of the takeover offer. The results suggest that the instrument, Delaware incorporation, is a significant determinant of having a provision. The F-statistic (67.15) is also higher than the critical value of 16.38 proposed by Stock and Yogo (2005). Models 2-5 report the second stage regressions estimating the effect of the instrumented presence of a provision on target premia. Following the extant literature, I use several proxies for takeover premia including the target Fama-French-Carhart four-factor adjusted cumulative abnormal return over the $[-1,+1],[-2$, $+2],[-5,+5]$, and $[-42,+30]$ windows around takeover announcements (Models 2-5, respectively).

After controlling for endogenous selection of adoption, the results in Models 2-5 suggest that firms with an exclusive forum provision receive higher takeover premia than targets without one. The economic effect is meaningful: a one standard deviation increase in the probability of having an exclusive forum provision is associated with a takeover premium that is between 5.9 and 7.4 percentage points higher. ${ }^{35}$ This represents an $18 \%-23 \%$ increase in the average premia for this sample, which is roughly \$17-\$24 million for the median-sized takeover target. Overall, Tables 7-9 suggest that exclusive forum provisions create value by reducing direct costs associated with multi-forum lawsuits and significantly decreasing the risk of claims with little or no legal merit.

\section{Conclusion}

Shareholders' ability to discipline management and the board using litigation is an important option available to align the interests of managers, directors, and shareholders. In recent years,

\footnotetext{
${ }^{35}$ The economic effect is calculated as follows: standard deviation of the fitted value from first stage multiplied by the coefficient on Provision Adopter in each model: for example in Model $2(0.1555 * 0.439)=0.068$.
} 
many firms have responded to an increased threat of multi-jurisdictional lawsuits by adopting exclusive forum provisions. These provisions change how shareholders can pursue fiduciary duty claims, which make up a significant portion of shareholder litigation (Thompson and Thomas, 2004), by designating courts in the firm's state of incorporation as the sole venue for these suits. This study examines the shareholder wealth effects and litigation consequences of a required venue for litigation. While much of the evidence in the paper focuses on Delaware-incorporated firms, provision adoption and changes to corporation law codifying these provisions have propagated to other states (i.e. provision adoption in Nevada and corporate law changes in New Jersey).

The results indicate that firms with a higher likelihood of facing shareholder litigation are the companies most likely to adopt a provision. Firm value increases around provision adoption for firms that are likely to be subject to shareholder suits. In addition, the market reacts positively around several exogenous events that validated and enforced the specifying of a required forum for shareholder claims. These gains in firm value suggest that multi-jurisdictional shareholder litigation imposes significant costs on firms and that shareholders view the domicile court as the appropriate venue for shareholder claims. Companies that adopt a required forum for litigation receive fewer lawsuits in fewer forums but are subject to litigation at the same rate as non-adopting firms. This suggests that limiting shareholder suits to the domicile court does not reduce the opportunity for shareholders to discipline managers and directors. A specified forum for litigation, however, does reduce direct legal costs of duplicative and low quality lawsuits. This reduction in litigation-related costs translates to higher takeover premia for target firms with exclusive forum provisions. In conclusion, the ability to specify a required venue for shareholder suits has positive firm value implications, especially for those firms most likely to face such litigation. 


\section{Acknowledgements}

I am grateful for the comments and suggestions of Douglas Cumming, the editor, two anonymous reviewers, David Becher, Naveen Daniel, Evan Dudley, Randy Heron, Feng Jiang, Jonathan Karpoff, Michelle Lowry, Shawn Mobbs, David Moore, Tod Perry, Simone Sepe, Ralph Walkling and seminar participants at the 2019 Midwest Finance Association Annual Meeting, the 2015 American Law and Economics Association Annual Meeting, the 2014 Conference on Empirical Legal Studies, the 2015 Eastern Finance Association Annual Meeting, the 2015 Financial Management Association Annual Meeting, the 2015 Southern Finance Association Annual Meeting, Drexel University, and the Kelley School of Business - Indianapolis. Prior versions of this paper were circulated under the title "The Value of Venue in Corporate Litigation: Evidence from Exclusive Forum Provisions.” 


\section{References}

Akyol, A., Lim, W., and Verwijmeren, P., 2012. "Shareholders in the Boardroom: Wealth Effects of the SEC's Proposal to Facilitate Director Nominations.” Journal of Financial and Quantitative Analysis 47, 1029-1057.

Allen, C., 2012. "Study of Delaware Forum Selection in Charters and Bylaws.” Unpublished working paper.

Allen, C., 2014. “Trends in Exclusive Forum Bylaws.” The Conference Board Governance Center - Director Notes.

Appel, I., 2019. “Governance by Litigation.” Unpublished working paper.

Arena, M., and Julio, B., 2015. "The Effects of Securities Class Action Litigation on Corporate Liquidity and Investment Policy.” Journal of Financial and Quantitative Analysis 50, 251275.

Armour, J., Black, B., and Cheffins, B., 2012. “Is Delaware Losing its Cases?” Journal of Empirical Legal Studies 9, 605-656.

Bebchuk, L., 1992. "Federalism and the Corporation: The Desirable Limits on State Competition in Corporate Law.” Harvard Law Review 105, 1435-1510.

Bebchuk, L., 1996. "A New Theory Concerning the Credibility and Success of Threats to Sue.” Journal of Legal Studies 25, 1-25.

Bebchuk, L., and Cohen, A., 2005. “The Costs of Entrenched Boards.” Journal of Financial Economics 78, 409-433.

Bhagat, S., Brickley, J., and Coles, J., 1987. "The Costs of Inefficient Bargaining and Financial Distress: Evidence from Corporate Lawsuits.” Journal of Financial Economics 25, 221-47.

Bizjak, J. and Coles, J., 1995. "The Effect of Private Antitrust Litigation on the Stock-Market Valuation of the Firm.” American Economic Review 85, 436-61.

Black, B., Cheffins, B., and Klausner, M., 2006. “Outside Director Liability.” Stanford Law Review 58, 1055-1160.

Bourveau, T., Lou, Y., and Wang, R., 2018. "Shareholder Litigation and Corporate Disclosure: Evidence from Derivative Lawsuits.” Journal of Accounting Research 56, 797-842.

Bouwman, C., 2011. "Corporate Governance Propagation through Overlapping Directors." Review of Financial Studies 24, 2358-2394.

Bradley, M., and Chen, D., 2011. "Corporate Governance and the Cost of Debt: Evidence from Director Limited Liability and Indemnification Provisions.” Journal of Corporate Finance 17, 83-107.

Brickley, J., Coles, J., and Terry, R., 1994. “Outside Directors and the Adoption of Poison Pills.” Journal of Financial Economics 35, 371-390.

Brochet, F. and Srinivasan, S., 2014. "Accountability of Independent Directors: Evidence from Firms Subject to Securities Litigation.” Journal of Financial Economics 111, 430-49.

Cai, J., Song, M., and Walkling, R., 2011. "Anticipation, Acquisitions, and Bidder Returns: Industry Shocks and the Transfer of Information across Rivals.” Review of Financial Studies 24, 2242-2285.

Cai, J., and Walkling, R., 2011. "Shareholders' Say on Pay: Does it Create Value?” Journal of Financial and Quantitative Analysis 46, 299-339.

Cain, M. and Solomon, S.D., 2013. “Takeover Litigation in 2012.” Unpublished working paper.

Cain, M., Fisch, J., Solomon, S.D., Thomas, R., 2018. “The Shifting Tides of Merger Litigation.” Vanderbilt Law Review 71, 603-640. 


\section{References (continued)}

Cain, M., Fisch, J., Solomon, S.D., Thomas, R., 2019. “Mootness Fees.” Vanderbilt Law Review 72, 1777-1816.

Cary, W., 1974. "Federalism and Corporate Law: Reflections upon Delaware.” Yale Law Journal 83, 663-705.

Chalmers, J., Dann, L., and Harford, J., 2002. "Managerial Opportunism? Evidence from Directors’ and Officers’ Insurance Purchases.” Journal of Finance 57, 609-36.

Cheng, C., Huang, H., Li, Y., and Lobo, G., 2010. "Institutional Monitoring through Shareholder Litigation.” Journal of Financial Economics 95, 356-83.

Coates, J., 2000. "Takeover Defenses in the shadow of the Pill: A Critique of the Scientific Evidence.” Texas Law Review 79, 271-382.

Coles, J., Daniel, N., and Naveen, L., 2014. “Co-opted Boards.” Review of Financial Studies 27, 1751-1796.

Crane, A. and Koch, A., 2018. "Shareholder Litigation and Ownership Structure: Evidence from a Natural Experiment.” Management Science 64, 5-23.

Cremers, K.J., Nair, V. B., and John, K., 2009. "Takeovers and the Cross-Section of Returns." Review of Financial Studies 22, 1409-1445.

Dari-Mattiacci, G., and Talley, E., 2019. "Being True to Trulia: Do Disclosure-Only Settlements in Merger Objection Lawsuits Harm Shareholders?” Unpublished working paper.

Donelson, D., and Yust, C., 2014. "Litigation Risk and Agency Costs: Evidence from Nevada Corporate Law.” Journal of Law and Economics 57, 747-780.

Dyck, A., Morse, A., and Zingales, L., 2010. "Who Blows the Whistle on Corporate Fraud?” Journal of Finance 65, 2213-2253.

Erickson, J., 2010. “Corporate Governance in the Courtroom: An Empirical Analysis.” William and Mary Law Review 51, 1749-1831.

Fama, E. and Jensen, M., 1983. "Separation of Ownership and Control.” Journal of Law and Economics 26, 301-25.

Ferris, S., Jandik, T, Lawless, R., and Makhija, A., 2007. "Derivative Lawsuits as a Corporate Governance Mechanism: Empirical Evidence on Board Changes Surrounding Filing.” Journal of Financial and Quantitative Analysis 42, 143-165.

Fich, E. and Shivdasani, A., 2006. “Are Busy Boards Effective Monitors?” Journal of Finance 61, 689-24.

Fich, E. and Shivdasani, A., 2007. "Financial Fraud, Director Reputation, and Shareholder Wealth.” Journal of Financial Economics 86, 306-36.

Fisch, J., Griffith, S., Solomon, S., 2015. "Confronting the Peppercorn Settlement in Merger Litigation: An Empirical Analysis and a Proposal for Reform.” Texas Law Review 93, 557624.

Field, L., Lowry, M., and Shu, S., 2005. “Does Disclosure Deter or Trigger Litigation?” Journal of Accounting and Economics 39, 487-507.

Francis, J., Philbrick, D., and Schipper, K., 1994. "Shareholder Litigation and Corporate Disclosures.” Journal of Accounting Research 32, 137-164.

Gande, A., and Lewis, C., 2009. "Shareholder-Initiated Class Action Lawsuits: Shareholder Wealth Effects and Industry Spillovers.” Journal of Financial and Quantitative Analysis 44, 823-850. 


\section{References (continued)}

Grundfest, J., 2012. “The History and Evolution of Intra-Corporate Forum Selection Clauses: An Empirical Analysis.” Delaware Journal of Corporate Law 37, 333-352.

Hanley, K. and Hoberg, G., 2012. "Litigation Risk, Strategic Disclosure and the Underpricing of Initial Public Offerings.” Journal of Financial Economics 103, 235-254.

Helland, E., 2006. "Reputational Penalties and the Merits of Class-Action Securities Litigation.” Journal of Law and Economics 49, 365-395.

Jensen, M., 1993. "The Modern Industrial Revolution, Exit, and the Failure of Internal Control Systems.” Journal of Finance 48, 831-80.

Johnson, M., Kasznik, R., and Nelson, K., 2000. "Shareholder Wealth Effects of the Private Securities Litigation Reform Act of 1995.” Review of Accounting Studies 5, 217-233.

Karpoff, J., Lee, D. S., and Martin, G., 2008. “The Cost to Firms of Cooking the Books.” Journal of Financial and Quantitative Analysis 43, 581-611.

Kempf, E., and Spalt, O., 2019. "Litigating Innovation: Evidence from Securities Class Action Lawsuits." Unpublished working paper.

Kim, I. and Skinner, D., 2012. “Measuring Securities Litigation Risk.” Journal of Accounting and Economics 53, 290-310.

Krishnan, C.N.V., Masulis, R., Thomas, R., and Thompson, R., 2012. "Shareholder Litigation in Mergers and Acquisitions.” Journal of Corporate Finance 18, 1248-1268.

Krishnan, C.N.V., Solomon, S. D., and Thomas, R.S., 2017. “The Impact on Shareholder Value of Top Defense Counsel in Mergers and Acquisitions Litigation.” Journal of Corporate Finance 45, 480-495.

Li, H., Pincus, M., and Rego, S.O., 2008. "Market Reaction to Events Surrounding the SarbanesOxley Act of 2002 and Earnings Management.” Journal of Law and Economics 51, 111-134.

Lin, C., Officer, M., and Zou, H., 2011. “Directors' and Officers' Liability Insurance and Acquisition Outcomes.” Journal of Financial Economics 102, 507-525.

Nguyen, H., Phan, H., and Sun, L., 2018. "Shareholder Litigation Rights and Corporate Cash Holdings: Evidence from Universal Demand Laws.” Journal of Corporate Finance 52, 192213.

Ni, X., and Yin, S., 2018. "Shareholder Litigation Rights and the Cost of Debt: Evidence from Derivative Lawsuits.” Journal of Corporate Finance 48, 169-186.

Pagan, A., 1984. "Econometric Issues in the Analysis of Regressions with Generate Regressors." International Economic Review 25, 154-193.

Pukthuanthong, K., Turtle, H., Walker, T., and Wang, J., 2017. "Litigation Risk and Institutional Monitoring." Journal of Corporate Finance 45, 342-359.

Romano, R., 1991. “The Shareholder Suit: Litigation Without Foundation?” Journal of Law, Economics, and Organization 7, 55-87.

Romano, R. and Sanga, S., 2017. “The Private Ordering Solution to Multiforum Shareholder Litigation.” Journal of Empirical Legal Studies 14, 31-78

Schwert, G., 1981. “Using Financial Data to Measure Effects of Regulation.” Journal of Law and Economics 24, 121-158.

Stock, J. and Yogo, M., 2005. “Testing for Weak Instruments in Linear IV Regression.” In: Andrews DWK Identification and Inference for Econometric Models. New York: Cambridge University Press: 80-108.

Thomas, R. and Thompson, R., 2004. “The New Look of Shareholder Litigation: Acquisitionoriented Class Action.” Vanderbilt Law Review 57, 133. 
Appendix A: Variable Definitions

Variable Definition

Panel A: Lawsuit Likelihood Measures

Derivative Lawsuit Probability

The fitted value from a panel regression estimating the probability that a firm will be subject to a shareholder derivative lawsuit in state court (Appendix B)

Class Action Lawsuit Probability The fitted value from a panel regression estimating the probability that a firm will be subject to a shareholder class action lawsuit in state court (Appendix B)

Shareholder Lawsuit Probability The fitted value from a panel regression estimating the probability that a firm will be subject to a shareholder derivative or class action lawsuit in state court (Appendix B)

High Litigation Industry

Indicator equal to one if a firm is in the biotech (SIC codes 2833-2836 and 8731-8734), computer (SIC codes 3570-3577 and 7370-7374), electronics (SIC codes 3600-3674), or retail (SIC codes 5200-5961) industry

\section{Panel B: Takeover Likelihood Measures}

Takeover Probability

The fitted value from a panel regression estimating the probability that a firm will be subject to a takeover offer (Appendix B)

\section{Panel C: Firm Characteristics}

$\begin{array}{ll}\text { Firm Size } & \text { Natural log of total market capitalization } \\ \text { ROA } & \text { Operating income scaled by total book value of assets } \\ \text { Tobin's Q } & \text { Market value of firm scaled by total book value of assets } \\ \text { FCF } & \text { Operating cash flow minus dividends scaled by total book value of assets } \\ \text { R\&D } & \text { Research and development expenditures scaled by total book value of assets } \\ \text { Leverage } & \text { Total book value of debt scaled by total book value of assets } \\ \text { PPE } & \text { Property, plant, and equipment scaled by total book value of assets } \\ \text { Sales Growth } & \text { Sales less prior fiscal year sales scaled by total book value of assets } \\ \text { Industry Takeover Activity } & \text { Number of firms with the same FFI12 industry code that are acquired during } \\ & \text { the previous fiscal year } \\ \text { Stock Return } & \text { One-year buy and hold market-adjusted return in prior fiscal year } \\ \text { Return Volatility } & \text { Standard deviation of daily returns over prior fiscal year } \\ \text { Skewness } & \text { Skewness of daily returns over prior fiscal year } \\ \text { Stock Turnover } & \text { Average daily volume scaled by average daily shares outstanding over prior } \\ & \text { fiscal year } \\ \text { Outside Directorship Adoption } & \text { Exclusive forum provision adoption rate at other board seats for each director } \\ & \text { weighted by their number of outside directorships - this measure is then } \\ \text { averaged over each board and scaled by board size }\end{array}$




\section{Appendix A: Variable Definitions (continued)}

\section{Panel D: Governance Characteristics}

$\begin{array}{ll}\begin{array}{l}\text { Independence } \\ \text { Co-option }\end{array} & \begin{array}{l}\text { Percentage of independent directors on the board } \\ \text { Percentage of independent directors on the board with tenure less than the } \\ \text { tenure of the current CEO } \\ \text { Percentage of independent directors on the board with greater than or equal to } \\ \text { three public directorships } \\ \text { Indicator equal to one if the CEO is also chair of the board }\end{array} \\ \text { CEO Chair } & \begin{array}{l}\text { Percentage of outstanding shares held by the top five institutional investors } \\ \text { Percentage of outstanding shares held by institutional investors with at least a } \\ \text { Top } 5 \text { Institutional Ownership } \\ \text { Blockholder Ownership }\end{array} \\ \text { Institutional Ownership HHI } & \begin{array}{l}\text { Herfindahl-Hirschman Index (HHI) of institutional ownership concentration } \\ \text { Percentage of outstanding shares held by the CEO }\end{array} \\ \text { CEO Ownership } & \text { Indicator equal to one if the firm has a classified board }\end{array}$




\section{Appendix B: Lawsuit and Takeover Probability Models}

The table reports logistic regressions modeling lawsuit and takeover probability. The dependent variable in Model 1 (Model 2) is an indicator equal to one if the firm was subject to a shareholder derivative (class action) lawsuit in state court in year $t$ and zero otherwise. The dependent variable in Model 3 is an indicator equal to one if the firm was subject to a shareholder derivative or class action lawsuit in state court in year $t$ and zero otherwise. The dependent variable in Model 4 is an indicator equal to one if the firm was subject to a takeover offer in year $t$ and zero otherwise. Coefficients are estimated for 25,544 firm-years over the 2009-2015 period. All independent variables are measured at the end of fiscal year $t-1$. High Litigation Industry is an indicator variable equal to one if a firm is in the biotech (SIC codes 2833-2836 and 8731-8734), computer (SIC codes 3570-3577 and 73707374), electronics (SIC codes 3600-3674), or retail (SIC codes 5200-5961) industry. Firm Size is the natural log of market capitalization. Stock Return is the one-year buy and hold market-adjusted return over prior fiscal year. Skewness is the skewness of daily returns over prior fiscal year. Return Volatility is the standard deviation of daily returns over prior fiscal year. Stock Turnover is the average daily volume scaled by average daily shares outstanding over prior fiscal year. Tobin's Q is market value of the firm scaled by total book value of assets. Sales Growth is sales less prior fiscal year sales scaled by total book value of assets. FCF is operating cash flow minus dividends scaled by total book value of assets. Leverage is total debt scaled by total book value of assets. ROA is operating income scaled by total book value of assets. Top 5 Institutional Ownership is the percent of shares held by the top five institutional investors. Industry Takeover Activity is the number of other firms in the same Fama-French 12 industry that are acquired during in a given sample year. Year fixed effects are included in all models. Industry (Fama-French 12) fixed effects are also included in Model 4. Coefficients reported are the marginal effects computed at the mean values of the independent variables. Marginal effects are the change in the probability of a lawsuit/takeover bid for a one standard deviation change in a continuous variable or a shift from zero to one for an indicator variable. $p$-values based on standard errors clustered by Fama-French 12 industry classifications are in parentheses. ${ }^{* * *},{ }^{* *}$, and ${ }^{*}$ denote statistical significance at the 1\%, 5\%, and 10\% levels respectively.

\begin{tabular}{|c|c|c|c|c|c|}
\hline & Model 1 & Model 2 & Model 3 & & Model 4 \\
\hline & $\begin{array}{l}\text { Derivative } \\
\text { Lawsuit }\end{array}$ & $\begin{array}{l}\text { Class Action } \\
\text { Lawsuit }\end{array}$ & $\begin{array}{c}\text { Derivative/ } \\
\text { Class Action } \\
\text { Lawsuit }\end{array}$ & & $\begin{array}{c}\text { Takeover } \\
\text { Bid }\end{array}$ \\
\hline Intercept & $\begin{array}{c}-6.599^{* * *} \\
(0.000)\end{array}$ & $\begin{array}{c}-5.249^{* * *} \\
(0.000)\end{array}$ & $\begin{array}{l}-5.069^{* * *} \\
(0.000)\end{array}$ & Intercept & $\begin{array}{c}-1.970^{* * *} \\
(0.000)\end{array}$ \\
\hline $\begin{array}{l}\text { High Litigation } \\
\text { Industry }\end{array}$ & $\begin{array}{c}0.006^{* * *} \\
(0.000)\end{array}$ & $\begin{array}{l}0.021^{* * *} \\
(0.000)\end{array}$ & $\begin{array}{l}0.026^{* * *} \\
(0.000)\end{array}$ & Firm Size & $\begin{array}{c}-0.011^{* * *} \\
(0.000)\end{array}$ \\
\hline Firm Size & $\begin{array}{l}0.003^{* * *} \\
(0.000)\end{array}$ & $\begin{array}{l}0.008^{* * *} \\
(0.000)\end{array}$ & $\begin{array}{l}0.011^{* * *} \\
(0.000)\end{array}$ & Tobin’s Q & $\begin{array}{c}-0.004^{* * *} \\
(0.000)\end{array}$ \\
\hline Sales Growth & $\begin{array}{c}0.009^{* * *} \\
(0.004)\end{array}$ & $\begin{array}{c}0.005 \\
(0.382)\end{array}$ & $\begin{array}{l}0.013^{* *} \\
(0.049)\end{array}$ & FCF & $\begin{array}{c}0.022 \\
(0.256)\end{array}$ \\
\hline Stock Return & $\begin{array}{l}-0.001 \\
(0.371)\end{array}$ & $\begin{array}{l}-0.004 \\
(0.107)\end{array}$ & $\begin{array}{l}-0.004 \\
(0.163)\end{array}$ & Leverage & $\begin{array}{c}0.039^{* * *} \\
(0.003)\end{array}$ \\
\hline Skewness & $\begin{array}{l}-0.001 \\
(0.112)\end{array}$ & $\begin{array}{l}0.003^{* * *} \\
(0.007)\end{array}$ & $\begin{array}{c}0.002 \\
(0.155)\end{array}$ & ROA & $\begin{array}{c}0.001 \\
(0.959)\end{array}$ \\
\hline Return Volatility & $\begin{array}{l}0.027^{* * *} \\
(0.001)\end{array}$ & $\begin{array}{c}0.020 \\
(0.219)\end{array}$ & $\begin{array}{l}0.048^{* * *} \\
(0.010)\end{array}$ & PPE & $\begin{array}{l}-0.016^{*} \\
(0.088)\end{array}$ \\
\hline \multirow[t]{2}{*}{ Stock Turnover } & $\begin{array}{l}0.001^{* * *} \\
(0.000)\end{array}$ & $\begin{array}{l}0.001^{* * *} \\
(0.000)\end{array}$ & $\begin{array}{l}0.001^{* * *} \\
(0.000)\end{array}$ & $\begin{array}{l}\text { Top } 5 \text { Institutional } \\
\text { Ownership }\end{array}$ & $\begin{array}{l}0.058^{* * *} \\
(0.000)\end{array}$ \\
\hline & & & & $\begin{array}{l}\text { Industry Takeover } \\
\text { Activity }\end{array}$ & $\begin{array}{c}0.001^{* * *} \\
(0.004)\end{array}$ \\
\hline Observations & 25,544 & 25,544 & 25,544 & Observations & 25,544 \\
\hline Pseudo $r^{2}$ & 0.065 & 0.033 & 0.042 & Pseudo $r^{2}$ & 0.029 \\
\hline $\begin{array}{l}\text { Year Fixed } \\
\text { Effects }\end{array}$ & Yes & Yes & Yes & $\begin{array}{l}\text { Year \& Industry } \\
\text { Fixed Effects }\end{array}$ & Yes \\
\hline
\end{tabular}




\section{Table 1: Exclusive Forum Provision Characteristics}

The table reports summary statistics on provision characteristics for 782 firms that adopted an exclusive forum provision through December 31, 2015 with available information in Compustat and CRSP. Panel A reports characteristics on whether the exclusive forum provision was adopted as an already public company (midstream adoption) or at the time of the IPO, whether the exclusive forum provision was adopted into the corporate bylaws or corporate charter, whether the exclusive forum provision was adopted as a stand-alone amendment or in conjunction with other amendments (combined amendment) and whether the exclusive forum provision was adopted before or after the Boilermakers decision (June 25, 2013). Panel B reports the temporal distribution of exclusive forum provision adoptions by year (5 firms adopt prior to 2010). Panel C reports the industry distribution of exclusive forum provision adopters by Fama-French 12 industry classification. Panel D reports the top five states selected as the exclusive forum, the top five states of incorporation and the top five states of headquarters for the sample of provision adopters.

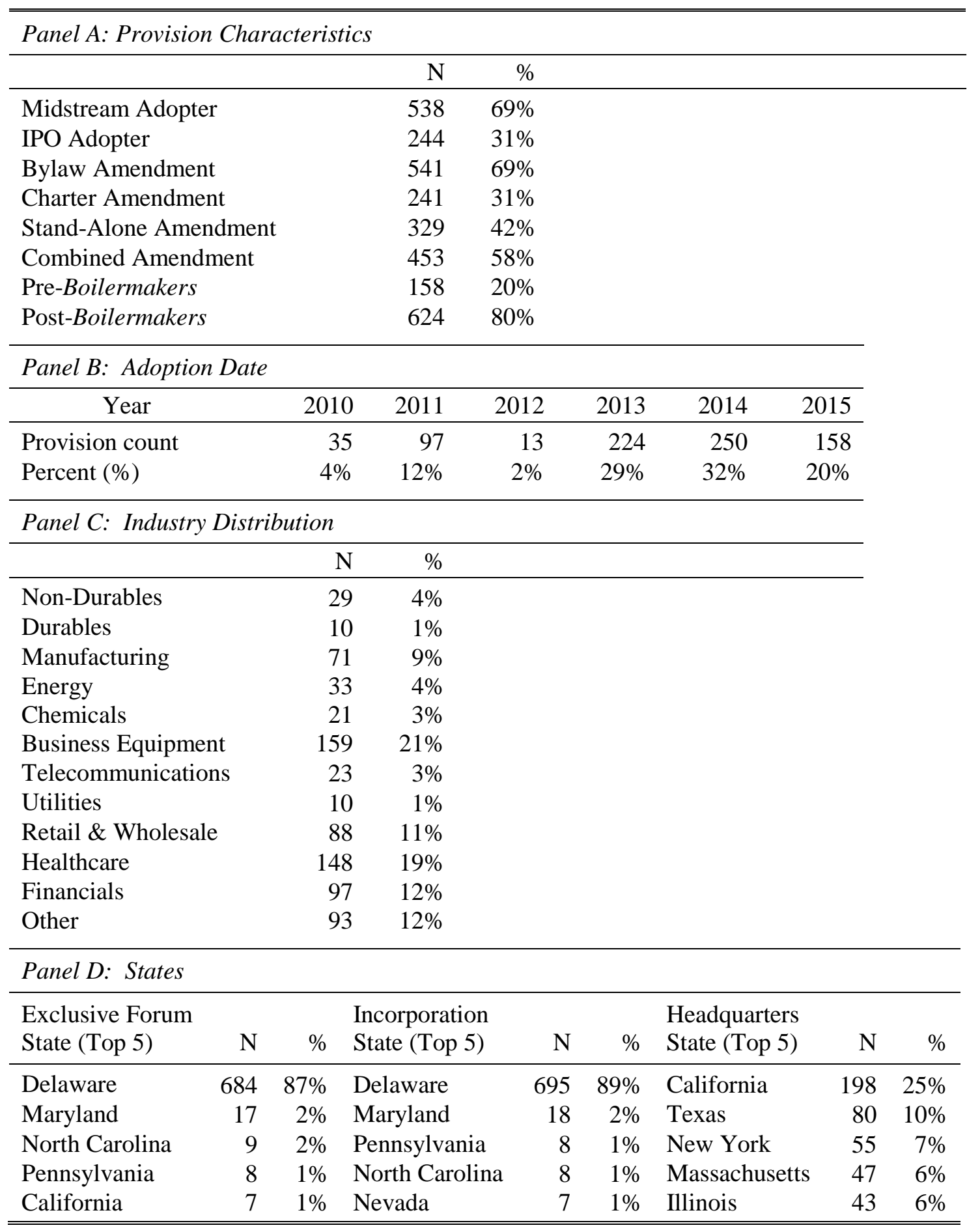




\section{Table 2: Firm Characteristics of Exclusive Forum Provision Adopters}

The table reports sample means for firm-year observations with non-missing data in Compustat and CRSP for fiscal years 20092015. Column 1 includes 526 firm-years in which a firm adopted an exclusive forum provision. Column 2 includes 23,285 nonadoption firm-years. Firm-years with an exclusive forum provision already in place are excluded from the non-adoption firm-year sample. The final column is the difference in means between adopting and non-adopting firm-years. Panel A includes measures of lawsuit and takeover likelihood. Derivative Lawsuit Probability is the fitted value from a panel regression estimating the probability that a firm will be subject to a shareholder derivative lawsuit in state court (Appendix B). Class Action Lawsuit Probability is the fitted value from a panel regression estimating the probability that a firm will be subject to a shareholder class action lawsuit in state court (Appendix B). Shareholder Lawsuit Probability is the fitted value from a panel regression estimating the probability that a firm will be subject to a shareholder derivative or class action lawsuit in state court (Appendix B). High Litigation Industry is an indicator equal to one if a firm is in the biotech (SIC codes 2833-2836 and 8731-8734), computer (SIC codes 3570-3577 and 7370-7374), electronics (SIC codes 3600-3674), or retail (SIC codes 5200-5961) industry. Takeover Probability is the fitted value from a panel regression estimating the probability that a firm will be subject to a takeover offer (Appendix B). Panel B includes other firm characteristics measured in the fiscal year prior to provision adoption. Firm Size is the natural log of total market capitalization. ROA is operating income scaled by total book value of assets. Tobin's Q is market value of the firm scaled by total book value of assets. FCF is operating cash flow minus dividends scaled by total book value of assets. Leverage is total book value of debt scaled by total book value of assets. R\&D is research and development expenditures scaled by total book value of assets. Stock Return is the one-year buy and hold abnormal return over the prior fiscal year. Return Volatility is the standard deviation of daily return over the fiscal year. Delaware Incorporation is an indicator equal to one if the firm's state of incorporation is Delaware. Different Inc./HQ is an indicator equal to one if the firm's state of incorporation is different from its state of headquarters. Panel C includes firm governance characteristics measured in the fiscal year prior to provision adoption. Independence is the percentage of independence directors on the board. Co-option is the percentage of independent directors on the board with tenure less than the tenure of the current CEO. Busy is the percentage of independent directors on the board with greater than or equal to three public directorships. CEO Chair is an indicator equal to one if the CEO is also chair of the board. Blockholder Ownership is the percentage of outstanding shares held by institutional investors with at least a 5\% ownership stake. Institutional Ownership HHI is the Herfindahl-Hirschman Index (HHI) of institutional ownership concentration. ${ }^{* * *},{ }^{* *}$, and ${ }^{*}$ denote statistically significant differences in means at the $1 \%, 5 \%$, and $10 \%$ levels respectively. 
Table 2: Firm Characteristics of Exclusive Forum Provision Adopters (continued)

Panel A: Lawsuit and Takeover Likelihood

\begin{tabular}{|c|c|c|c|}
\hline & $\begin{array}{r}\text { Adopters } \\
(1)\end{array}$ & $\begin{array}{r}\text { Non-Adopters } \\
\text { (2) }\end{array}$ & $(1)-(2)$ \\
\hline Derivative Lawsuit Probability & $1.9 \%$ & $1.7 \%$ & $0.3 \%^{* * *}$ \\
\hline Class Action Lawsuit Probability & $5.3 \%$ & $4.1 \%$ & $1.2 \%^{* * *}$ \\
\hline Shareholder Lawsuit Probability & $6.8 \%$ & $5.4 \%$ & $1.4 \%^{* * *}$ \\
\hline High Litigation Industry & $33.1 \%$ & $24.8 \%$ & $8.3 \%^{* * *}$ \\
\hline Takeover Probability & $6.4 \%$ & $6.4 \%$ & $0.0 \%$ \\
\hline \multicolumn{4}{|l|}{ Panel B: Firm Characteristics } \\
\hline & Adopters & Non-Adopters & \multirow{2}{*}{$(1)-(2)$} \\
\hline & (1) & (2) & \\
\hline Firm Size & 7.15 & 6.15 & $1.00^{* * *}$ \\
\hline ROA & $7.3 \%$ & $3.3 \%$ & $4.0 \%^{* * *}$ \\
\hline Tobin's Q & 2.07 & 1.86 & $0.21^{* * *}$ \\
\hline FCF & $3.8 \%$ & $0.9 \%$ & $2.9 \%^{* * *}$ \\
\hline Leverage & $22.5 \%$ & $20.9 \%$ & $1.6 \%$ \\
\hline $\mathrm{R} \& \mathrm{D}$ & $5.6 \%$ & $4.9 \%$ & $0.7 \%$ \\
\hline Stock Return & $2.8 \%$ & $0.3 \%$ & $2.5 \%$ \\
\hline Return Volatility & $10.4 \%$ & $12.6 \%$ & $-2.2 \%^{* * *}$ \\
\hline Delaware Incorporation & $84.2 \%$ & $58.9 \%$ & $25.3 \%^{* * *}$ \\
\hline Different Inc./HQ & $89.0 \%$ & $69.1 \%$ & $19.9 \%^{* * *}$ \\
\hline \multicolumn{4}{|c|}{ Panel C: Governance Characteristics } \\
\hline & Adopters & Non-Adopters & \multirow{2}{*}{$(1)-(2)$} \\
\hline & (1) & (2) & \\
\hline Independence & $77.5 \%$ & $75.1 \%$ & $2.4 \%^{* * *}$ \\
\hline Co-option & $48.0 \%$ & $47.1 \%$ & $0.9 \%$ \\
\hline Busy & $20.4 \%$ & $15.5 \%$ & $4.9 \%^{* * *}$ \\
\hline CEO Chair & $45.2 \%$ & $48.6 \%$ & $-2.4 \%$ \\
\hline Blockholder Ownership & $21.8 \%$ & $18.8 \%$ & $3.0 \%{ }^{* * *}$ \\
\hline Institutional Own. HHI & $9.5 \%$ & $14.4 \%$ & $-4.9 \% * * *$ \\
\hline
\end{tabular}




\section{Table 3: Probability of Exclusive Forum Provision Adoption}

The table reports logistic regressions modeling the likelihood of exclusive forum provision adoption. The sample consists of 25,544 firm-year observations from 2009-2015. In each model, the dependent variable is an indicator equal to one if the firm adopts an exclusive forum provision in that fiscal year and zero otherwise. Panel A reports the results for the full sample of firm-years. Derivative Lawsuit Probability is the fitted value from a panel regression estimating the probability that a firm will be subject to a shareholder derivative lawsuit in state court (Appendix B). Class Action Lawsuit Probability is the fitted value from a panel regression estimating the probability that a firm will be subject to a shareholder class action lawsuit in state court (Appendix B). Shareholder Lawsuit Probability is the fitted value from a panel regression estimating the probability that a firm will be subject to a shareholder derivative or class action lawsuit in state court (Appendix B). High Litigation Industry is an indicator equal to one if a firm is in the biotech (SIC codes 2833-2836 and 8731-8734), computer (SIC codes 3570-3577 and 7370-7374), electronics (SIC codes 3600-3674), or retail (SIC codes 5200-5961) industry. Takeover Probability is the fitted value from a panel regression estimating the probability that a firm will be subject to a takeover offer (Appendix B). Firm Size is the natural log of total market capitalization. Stock Return is the one-year buy and hold abnormal return over the prior fiscal year. FCF is operating cash flow minus dividends scaled by total book value of assets. Leverage is total book value of debt scaled by total book value of assets. R\&D is research and development expenditures scaled by total book value of assets. Institutional Ownership HHI is the HerfindahlHirschman Index (HHI) of institutional ownership concentration. Different Inc./HQ is an indicator equal to one if the firm's state of incorporate is different from firm's state of headquarters. All independent variables are measured at the end of the prior fiscal year. Panel B reports results for a sub-sample of firm-years with available firm governance characteristics. Independence is the percentage of independent directors on the board. Co-option is the percentage of independent directors on the board with tenure less than the tenure of the current CEO. Busy is the percentage of independent directors on the board with greater than or equal to three public directorships. CEO Chair is an indicator equal to one if the CEO is also chair of the board. Control variables not shown in Panel B include Firm Size, Stock Return, FCF, Leverage, R\&D, and Different Inc./HQ. Panel C reports results for a subsample of firm-years with available outside directorship information. Models 1-5 of Panel C include firm-years with available firm governance characteristics. Model 6 (7) of Panel C includes firm-years in the top (bottom three) quartile(s) of takeover probability for a given sample year. Outside Directorship Adoption is the exclusive forum provision adoption rate at other board seats for each director weighted by their number of outside directorship and then averaged over the board and scaled by board size. Year and industry fixed effects based on Fama-French 12 industry classifications are also included in all models and panels. Coefficients reported are the marginal effects computed at the mean values of the independent variables. Marginal effects are the change in the probability of exclusive forum provision adoption for a one standard deviation change in a continuous variable or a shift from zero to one for an indicator variable. $p$-values based on bootstrapped standard errors using 1,000 replications (clustered by Fama-French 12 industry classifications) are in parentheses for Models $1-3$ and 5 (4) to account for the generated regressors. ${ }^{* * *},{ }^{* *}$, and ${ }^{*}$ denote statistical significance at the $1 \%, 5 \%$, and $10 \%$ levels respectively. 
Table 3: Probability of Exclusive Forum Provision Adoption (continued)

\begin{tabular}{|c|c|c|c|c|c|}
\hline Panel A: Full Sample & Model 1 & Model 2 & Model 3 & Model 4 & Model 5 \\
\hline Intercept & $\begin{array}{c}-7.206^{* * *} \\
(0.000)\end{array}$ & $\begin{array}{c}-7.013^{* * *} \\
(0.000)\end{array}$ & $\begin{array}{c}-7.087^{* * *} \\
(0.000)\end{array}$ & $\begin{array}{c}-7.223^{* * *} \\
(0.000)\end{array}$ & $\begin{array}{c}-8.170^{* * *} \\
(0.000)\end{array}$ \\
\hline Derivative Lawsuit Probability & $\begin{array}{l}0.047^{* *} \\
(0.039)\end{array}$ & & & & \\
\hline Class Action Lawsuit Probability & & $\begin{array}{c}0.066^{* * *} \\
(0.000)\end{array}$ & & & \\
\hline Shareholder Lawsuit Probability & & & $\begin{array}{c}0.040^{* * *} \\
(0.001)\end{array}$ & & \\
\hline High Litigation Industry & & & & $\begin{array}{c}0.001^{* * *} \\
(0.000)\end{array}$ & \\
\hline Takeover Probability & & & & & $\begin{array}{l}0.057^{* *} \\
(0.017)\end{array}$ \\
\hline Firm Size & $\begin{array}{c}0.001^{* * *} \\
(0.000)\end{array}$ & $\begin{array}{c}0.001^{*} \\
(0.080)\end{array}$ & $\begin{array}{l}0.001^{* *} \\
(0.022)\end{array}$ & $\begin{array}{l}0.001^{* * *} \\
(0.000)\end{array}$ & $\begin{array}{c}0.002^{* * *} \\
(0.000)\end{array}$ \\
\hline Stock Return & $\begin{array}{c}-0.002^{* *} \\
(0.030)\end{array}$ & $\begin{array}{c}-0.002^{* *} \\
(0.034)\end{array}$ & $\begin{array}{c}-0.002^{* *} \\
(0.030)\end{array}$ & $\begin{array}{c}-0.002^{* *} \\
(0.031)\end{array}$ & $\begin{array}{c}-0.002^{* *} \\
(0.047)\end{array}$ \\
\hline FCF & $\begin{array}{c}0.010^{* * *} \\
(0.002)\end{array}$ & $\begin{array}{l}0.010^{* * *} \\
(0.002)\end{array}$ & $\begin{array}{c}0.010^{* * *} \\
(0.002)\end{array}$ & $\begin{array}{c}0.010^{* * *} \\
(0.003)\end{array}$ & $\begin{array}{l}0.008^{* *} \\
(0.017)\end{array}$ \\
\hline Leverage & $\begin{array}{c}0.000 \\
(0.973)\end{array}$ & $\begin{array}{l}-0.000 \\
(0.861)\end{array}$ & $\begin{array}{l}-0.000 \\
(0.891)\end{array}$ & $\begin{array}{c}0.000 \\
(0.782)\end{array}$ & $\begin{array}{l}-0.002 \\
(0.265)\end{array}$ \\
\hline $\mathrm{R} \& \mathrm{D}$ & $\begin{array}{l}0.010^{* *} \\
(0.039)\end{array}$ & $\begin{array}{l}0.010^{* *} \\
(0.047)\end{array}$ & $\begin{array}{l}0.010^{* *} \\
(0.047)\end{array}$ & $\begin{array}{c}0.009 \\
(0.146)\end{array}$ & $\begin{array}{l}0.012^{* *} \\
(0.016)\end{array}$ \\
\hline Institutional Ownership HHI & $\begin{array}{l}-0.008^{*} \\
(0.062)\end{array}$ & $\begin{array}{l}-0.009^{*} \\
(0.056)\end{array}$ & $\begin{array}{l}-0.008^{*} \\
(0.063)\end{array}$ & $\begin{array}{l}-0.009^{*} \\
(0.064)\end{array}$ & $\begin{array}{c}-0.006 \\
(0.135)\end{array}$ \\
\hline Different Inc./HQ & $\begin{array}{c}0.009^{* * *} \\
(0.000)\end{array}$ & $\begin{array}{c}0.009^{* * *} \\
(0.000)\end{array}$ & $\begin{array}{c}0.009^{* * *} \\
(0.000)\end{array}$ & $\begin{array}{c}0.009^{* * *} \\
(0.000)\end{array}$ & $\begin{array}{c}0.009^{* * *} \\
(0.000)\end{array}$ \\
\hline Year \& Industry Fixed Effects & Yes & Yes & Yes & Yes & Yes \\
\hline Observations & 25,544 & 25,544 & 25,544 & 25,544 & 25,544 \\
\hline Pseudo $r^{2}$ & 0.132 & 0.133 & 0.133 & 0.131 & 0.132 \\
\hline
\end{tabular}


Table 3: Probability of Exclusive Forum Provision Adoption (continued)

\begin{tabular}{|c|c|c|c|c|c|}
\hline Panel B: Governance Sample & Model 1 & Model 2 & Model 3 & Model 4 & Model 5 \\
\hline Intercept & $\begin{array}{c}-7.711^{* * *} \\
(0.000)\end{array}$ & $\begin{array}{c}-7.460^{* * *} \\
(0.000)\end{array}$ & $\begin{array}{c}-7.554^{* * *} \\
(0.000)\end{array}$ & $\begin{array}{c}-7.744^{* * *} \\
(0.000)\end{array}$ & $\begin{array}{c}-8.452^{* * *} \\
(0.000)\end{array}$ \\
\hline Derivative Lawsuit Probability & $\begin{array}{c}0.050^{*} \\
(0.088)\end{array}$ & & & & \\
\hline Class Action Lawsuit Probability & & $\begin{array}{l}0.071^{* * *} \\
(0.004)\end{array}$ & & & \\
\hline Shareholder Lawsuit Probability & & & $\begin{array}{c}0.042^{* * *} \\
(0.008)\end{array}$ & & \\
\hline High Litigation Industry & & & & $\begin{array}{l}0.002^{* * *} \\
(0.000)\end{array}$ & \\
\hline Takeover Probability & & & & & $\begin{array}{c}0.059^{*} \\
(0.076)\end{array}$ \\
\hline Independence & $\begin{array}{l}0.008^{* *} \\
(0.044)\end{array}$ & $\begin{array}{c}0.007^{*} \\
(0.080)\end{array}$ & $\begin{array}{c}0.007^{*} \\
(0.067)\end{array}$ & $\begin{array}{c}0.008^{* * *} \\
(0.006)\end{array}$ & $\begin{array}{c}0.007^{*} \\
(0.074)\end{array}$ \\
\hline Co-option & $\begin{array}{c}0.002^{*} \\
(0.092)\end{array}$ & $\begin{array}{c}0.002 \\
(0.158)\end{array}$ & $\begin{array}{c}0.002 \\
(0.134)\end{array}$ & $\begin{array}{c}0.003^{*} \\
(0.063)\end{array}$ & $\begin{array}{c}0.002^{*} \\
(0.096)\end{array}$ \\
\hline Busy & $\begin{array}{c}0.001 \\
(0.664)\end{array}$ & $\begin{array}{c}0.001 \\
(0.718)\end{array}$ & $\begin{array}{c}0.001 \\
(0.709)\end{array}$ & $\begin{array}{c}0.001 \\
(0.597)\end{array}$ & $\begin{array}{c}0.001 \\
(0.695)\end{array}$ \\
\hline CEO-Chair & $\begin{array}{c}-0.001 \\
(0.199)\end{array}$ & $\begin{array}{c}-0.001 \\
(0.216)\end{array}$ & $\begin{array}{l}-0.001 \\
(0.217)\end{array}$ & $\begin{array}{l}-0.001^{*} \\
(0.098)\end{array}$ & $\begin{array}{l}-0.001 \\
(0.233)\end{array}$ \\
\hline Institutional Ownership HHI & $\begin{array}{l}-0.007 \\
(0.178)\end{array}$ & $\begin{array}{c}-0.008 \\
(0.145)\end{array}$ & $\begin{array}{c}-0.008 \\
(0.164)\end{array}$ & $\begin{array}{c}-0.008 \\
(0.132)\end{array}$ & $\begin{array}{c}-0.006 \\
(0.305)\end{array}$ \\
\hline Year \& Industry Fixed Effects & Yes & Yes & Yes & Yes & Yes \\
\hline Observations & 22,569 & 22,569 & 22,569 & 22,569 & 22,569 \\
\hline Pseudo $r^{2}$ & 0.120 & 0.121 & 0.121 & 0.120 & 0.120 \\
\hline
\end{tabular}


Table 3: Probability of Exclusive Forum Provision Adoption (continued)

\begin{tabular}{|c|c|c|c|c|c|c|c|}
\hline \multirow[b]{2}{*}{ Panel C: Directorship Spillovers } & Model 1 & Model 2 & Model 3 & Model 4 & Model 5 & Model 6 & Model 7 \\
\hline & & & & & & $\begin{array}{c}\text { High } \\
\text { Takeover } \\
\text { Probability }\end{array}$ & $\begin{array}{c}\text { Low } \\
\text { Takeover } \\
\text { Probability }\end{array}$ \\
\hline Intercept & $\begin{array}{c}-7.078^{* * *} \\
(0.000)\end{array}$ & $\begin{array}{c}-6.898^{* * *} \\
(0.000)\end{array}$ & $\begin{array}{c}-6.965^{* * *} \\
(0.000)\end{array}$ & $\begin{array}{c}-7.098^{* * *} \\
(0.000)\end{array}$ & $\begin{array}{c}-7.899^{* * *} \\
(0.000)\end{array}$ & $\begin{array}{c}-8.526^{* * *} \\
(0.000)\end{array}$ & $\begin{array}{c}-6.739^{* * *} \\
(0.000)\end{array}$ \\
\hline Outside Directorship Adoption & $\begin{array}{c}0.022^{*} \\
(0.055)\end{array}$ & $\begin{array}{l}0.021^{*} \\
(0.069)\end{array}$ & $\begin{array}{c}0.021^{*} \\
(0.063)\end{array}$ & $\begin{array}{c}0.021^{* * *} \\
(0.007)\end{array}$ & $\begin{array}{c}0.021^{*} \\
(0.064)\end{array}$ & $\begin{array}{l}-0.013 \\
(0.625)\end{array}$ & $\begin{array}{l}0.031^{* * *} \\
(0.001)\end{array}$ \\
\hline Derivative Lawsuit Probability & $\begin{array}{c}0.058^{*} \\
(0.053)\end{array}$ & & & & & & \\
\hline Class Action Lawsuit Probability & & $\begin{array}{c}0.077^{* * *} \\
(0.002)\end{array}$ & & & & & \\
\hline Shareholder Lawsuit Probability & & & $\begin{array}{c}0.048^{* * *} \\
(0.003)\end{array}$ & & & & \\
\hline High Litigation Industry & & & & $\begin{array}{c}0.001^{*} \\
(0.054)\end{array}$ & & & \\
\hline Takeover Probability & & & & & $\begin{array}{l}0.061^{*} \\
(0.053)\end{array}$ & & \\
\hline Year \& Industry Fixed Effects & Yes & Yes & Yes & Yes & Yes & Yes & Yes \\
\hline Observations & 22,040 & 22,040 & 22,040 & 22,040 & 22,040 & 5,401 & 16,639 \\
\hline Pseudo $r^{2}$ & 0.120 & 0.121 & 0.121 & 0.120 & 0.120 & 0.129 & 0.120 \\
\hline
\end{tabular}




\section{Table 4: Exclusive Forum Provision Adoption Announcement Returns}

The table reports sample mean Fama-French-Carhart four-factor adjusted two-day [0, +1] cumulative abnormal returns (CARs) for a sample of 460 exclusive forum provision adoption announcements. The announcement date is defined as the 8-K filing date announcing the bylaw/charter change with the SEC. Any announcements with confounding events, such as merger or earnings announcements are excluded from the sample. Announcement returns are winsorized at the $1 \%$ and $99 \%$ levels. Panel A reports mean CARs for the full sample. Panel B sorts the sample into high/yes and low/no samples based on full sample median lawsuit likelihood measures. Derivative Lawsuit Probability is the fitted value from a panel regression estimating the probability that a firm will be subject to a shareholder derivative lawsuit in state court (Appendix B). Class Action Lawsuit Probability is the fitted value from a panel regression estimating the probability that a firm will be subject to a shareholder class action lawsuit in state court (Appendix B). Shareholder Lawsuit Probability is the fitted value from a panel regression estimating the probability that a firm will be subject to a shareholder derivative or class action lawsuit in state court (Appendix B). High Litigation Industry is an indicator equal to one if a firm is in the biotech (SIC codes 2833-2836 and 8731-8734), computer (SIC codes 3570-3577 and 73707374), electronics (SIC codes 3600-3674), or retail (SIC codes 5200-5961) industry. Panel B sorts the sample into high/yes and low/no samples based on full sample median takeover likelihood measures. Takeover Probability is the fitted value from a panel regression estimating the probability that a firm will be subject to a takeover offer in the following fiscal years (Appendix B). Panel $\mathrm{D}$ includes only adopting firms in industries with above median industry takeover activity. Panel E sorts the sample by Outside Directorship Adoption which is the exclusive forum provision adoption rate at other board seats for each director weighted by their number of outside directorship and averaged over the board and scaled by board size. Panel F sorts the sample into whether the firm is incorporated in a state that is different from its state of headquarters and whether the firm is incorporated in the state of Delaware. Panel G sorts the sample into high/yes and low/no samples based on full sample median governance characteristics. Independence is the percentage of independence directors on the board. Co-option is the percentage of independent directors on the board with tenure less than the tenure of the current CEO. Busy is the percentage of independent directors on the board with greater than or equal to three public directorships. CEO Chair is an indicator equal to one if the CEO is also chair of the board. Blockholder Ownership is the percentage of outstanding shares held by institutional investors with at least a 5\% ownership stake. Institutional Ownership HHI is the Herfindahl-Hirschman Index (HHI) of institutional ownership concentration. CEO Ownership is the percentage of outstanding shares held by the CEO. Classified Board is an indicator equal to one if the firm has a classified board. All firm characteristics are measured as of the fiscal year end prior to exclusive forum provision adoption. ${ }^{* * *},{ }^{* *}$, and ${ }^{*}$ denote statistically significant differences in means at the $1 \%, 5 \%$, and $10 \%$ levels respectively.

\begin{tabular}{|c|c|c|c|c|c|c|c|c|}
\hline \multicolumn{9}{|c|}{ Panel A: Full Sample } \\
\hline & $\mathrm{N}$ & Mean & \multicolumn{2}{|c|}{ Median } & \multicolumn{2}{|c|}{ Std. Dev. } & Q1 & Q3 \\
\hline Full Sample & 460 & $0.19 \%$ & \multicolumn{2}{|c|}{$0.03 \%$} & \multicolumn{2}{|c|}{$3.03 \%$} & $-1.17 \%$ & $1.46 \%$ \\
\hline \multirow{2}{*}{\multicolumn{3}{|c|}{ Panel B: Lawsuit Likelihood }} & \multicolumn{4}{|c|}{ High/Yes } & \multicolumn{2}{|l|}{ Low/No } \\
\hline & & & $\mathrm{N}$ & Avg & & $\mathrm{N}$ & Avg. CAR & High-Low \\
\hline \multirow{4}{*}{\multicolumn{3}{|c|}{$\begin{array}{l}\text { Derivative Lawsuit Probability } \\
\text { Class Action Lawsuit Probability } \\
\text { Shareholder Lawsuit Probability } \\
\text { High Litigation Industry }\end{array}$}} & 298 & & & 162 & $0.12 \%$ & $0.11 \%$ \\
\hline & & & 301 & & & 159 & $-0.29 \%$ & $0.69 \%^{* *}$ \\
\hline & & & 305 & & & 155 & $-0.32 \%$ & $0.73 \%^{* *}$ \\
\hline & & & 146 & & & 314 & $-0.04 \%$ & $0.65 \%{ }^{* *}$ \\
\hline \multirow{2}{*}{\multicolumn{3}{|c|}{ Panel C: Takeover Likelihood }} & \multicolumn{4}{|c|}{ High/Yes } & \multicolumn{2}{|l|}{ Low/No } \\
\hline & & & $\mathrm{N}$ & Avg & AR & $\mathrm{N}$ & Avg. CAR & High-Low \\
\hline \multicolumn{3}{|c|}{ Takeover Probability } & 223 & & & 237 & $-0.21 \%$ & $0.78 \%^{* * *}$ \\
\hline
\end{tabular}


Table 4: Exclusive Forum Provision Adoption Announcement Returns (continued)

\begin{tabular}{|c|c|c|c|c|c|}
\hline \multirow[t]{2}{*}{ Panel D: Industry Takeover Activity } & \multicolumn{2}{|r|}{ High/Yes } & \multicolumn{2}{|r|}{ Low/No } & \multirow[b]{2}{*}{ High-Low } \\
\hline & $\mathrm{N}$ & Avg. CAR & $\mathrm{N}$ & Avg. CAR & \\
\hline \multicolumn{6}{|c|}{ Above Median Industry Takeover Activity: } \\
\hline Takeover Probability & 162 & $0.80 \% \%^{* * *}$ & 162 & $-0.34 \%$ & $1.14 \%^{* * *}$ \\
\hline \multirow[t]{2}{*}{ Panel E: Overlapping Directors } & & High & & Low & \\
\hline & $\mathrm{N}$ & Avg. CAR & $\mathrm{N}$ & Avg. CAR & High-Low \\
\hline Outside Directorship Adoption & 74 & $0.03 \%$ & 363 & $0.20 \%$ & $-0.17 \%$ \\
\hline \multirow[t]{2}{*}{ Panel F: State of Incorporation } & & Yes & & No & \\
\hline & $\mathrm{N}$ & Avg. CAR & $\mathrm{N}$ & Avg. CAR & Yes-No \\
\hline Different Inc./HQ & 406 & $0.23 \%$ & 54 & $-0.29 \%$ & $0.52 \%$ \\
\hline Delaware Incorporation & 385 & $0.14 \%$ & 75 & $0.30 \%$ & $-0.16 \%$ \\
\hline \multirow[t]{2}{*}{ Panel G: Type of Provision } & & Yes & & No & \\
\hline & $\mathrm{N}$ & Avg. CAR & $\mathrm{N}$ & Avg. CAR & Yes-No \\
\hline Bylaw Amendment & 446 & $0.14 \%$ & 14 & $0.70 \%$ & $-0.56 \%$ \\
\hline \multirow[t]{2}{*}{ Panel H: Governance } & & High/Yes & & Low/No & \\
\hline & $\mathrm{N}$ & Avg. CAR & $\mathrm{N}$ & Avg. CAR & High-Low \\
\hline Independence & 253 & $0.42 \%{ }^{* *}$ & 207 & $-0.15 \%$ & $0.57 \%^{* *}$ \\
\hline Co-option & 228 & $0.21 \%$ & 232 & $0.12 \%$ & $0.09 \%$ \\
\hline Busy & 274 & $0.17 \%$ & 186 & $0.16 \%$ & $0.01 \%$ \\
\hline CEO Chair & 209 & $0.00 \%$ & 251 & $0.30 \%$ & $-030 \%$ \\
\hline Blockholder Ownership & 257 & $0.25 \%$ & 203 & $0.06 \%$ & $0.19 \%$ \\
\hline Institutional Ownership HHI & 165 & $0.06 \%$ & 295 & $0.23 \%$ & $-0.17 \%$ \\
\hline CEO Ownership & 263 & $0.09 \%$ & 181 & $0.30 \%$ & $-0.21 \%$ \\
\hline Classified Board & 212 & $0.15 \%$ & 237 & $0.21 \%$ & $-0.06 \%$ \\
\hline
\end{tabular}




\section{Table 5: Market Reaction to Boilermakers Decision}

The table reports portfolio returns for all Delaware-incorporated firms with non-missing information in Compustat and CRSP around the Boilermakers decision on June 25, 2013. Portfolio returns are equal-weighted Fama-French-Carhart four-factor model returns over the 2-day window $[0,+1]$ surrounding the Boilermakers decision estimated using equation (1). Each portfolio return represents an average two-day CAR and is calculated by multiplying the $\beta_{5}$ coefficient from Equation (1), which captures the average daily abnormal return during the event window, by two. The pre-event estimation period for the Boilermakers decision begins on February 7, 2012, the date that shareholders of twelve Delaware-incorporated firms filed lawsuits against each firm's board of directors over their existing exclusive forum provisions, and spans 330 trading days until May 31, 2013. There is a fifteen day gap between the end of the estimation windows and the event windows to avoid contamination from information leakage prior to the event. Panel A reports the portfolio return for all Delaware incorporated firms in the sample. Panels B and C sort portfolios based on exclusive forum provision adoption and lawsuit probability measures. Panel B contains a comparison of firms with a bylaw provision at the time of the Boilermakers decision to firms without a provision at the time of the decision. This panel also sorts adopting firms by above and below median Shareholder Lawsuit Probability, which is the fitted value from a panel regression estimating the probability that a firm will be subject to a shareholder derivative or class action lawsuit in state court (Appendix B). Panel C reports results for portfolios sorted by Shareholder Lawsuit Probability. All firm characteristics are measured as of the fiscal year end prior to the Boilermakers decision. ${ }^{* * *},{ }^{* *}$, and ${ }^{*}$ denote statistical significance at the $1 \%, 5 \%$, and $10 \%$ levels respectively.

Panel A: All Delaware Incorporated Firms

\begin{tabular}{lccc}
\hline & \# of Firms & Portfolio CAR (\%) & t-stat \\
\hline All Delaware Incorporated Firms & 2,188 & $0.148 \%$ & $4.04^{* * *}$ \\
\hline
\end{tabular}

Panel B: Pre-Boilermakers Bylaw Adopters

\begin{tabular}{|c|c|c|c|c|}
\hline & \# of Firms & & Portfolio CAR (\%) & t-stat \\
\hline Firms Without Provision at Decision & 2,049 & & $0.129 \%$ & $3.67^{* * *}$ \\
\hline \multirow[t]{2}{*}{ Pre-Boilermakers Bylaw Adopters } & 65 & & $0.410 \%$ & 1.51 \\
\hline & & Diff (Pre-Without) & $0.281 \%$ & 1.07 \\
\hline High Shareholder Lawsuit Prob. & 40 & & $0.873 \%$ & $4.66^{* * *}$ \\
\hline \multirow[t]{2}{*}{ Low Shareholder Lawsuit Prob. } & 25 & & $-0.367 \%$ & -0.84 \\
\hline & & Diff (High-Low) & $1.240 \%$ & $4.24^{* * *}$ \\
\hline
\end{tabular}

Panel C: Shareholder Lawsuit Probability

\begin{tabular}{lcccc}
\hline & \# of Firms & Lawsuit Prob. & Portfolio CAR (\%) & t-stat \\
\hline 1 Lowest & 547 & $2.4 \%$ & $-0.220 \%$ & $-2.75^{* * *}$ \\
2 & 547 & $3.8 \%$ & $-0.062 \%$ & -0.92 \\
3 & 547 & $5.3 \%$ & $0.181 \%$ & 1.41 \\
4 Highest & 547 & $9.2 \%$ & $0.666 \%$ & $4.33^{* * *}$ \\
& & Diff $(4-1)$ & $0.886 \%$ & $4.34^{* * *}$ \\
\hline \hline
\end{tabular}




\section{Table 6: Market Reaction to State Court Enforcements of Exclusive Forum Provisions}

The table reports the market reaction to three state court rulings that enforced exclusive forum provisions by dismissing lawsuits filed outside of the defendant firms' exclusive forum. The first court ruling is the HEMG Inc. v. Aspen University decision in the New York Supreme Court for New York County on November 4, 2013. The portfolio of firms analyzed around this decision includes 210 New York headquartered firms that are also incorporated in Delaware. The second court ruling is the Miller v. Beam decision in the Illinois Chancery Court of Cook County on March 5, 2014. The portfolio of firms analyzed around this decision includes 127 Illinois headquartered firms that are also incorporated in Delaware. The third court ruling is the Groen v. Safeway Inc. decision in the Superior Court of California, Alameda County on May 14, 2014. The portfolio of firms analyzed around this decision includes 503 California headquartered firms that are also incorporated in Delaware. Portfolio returns are equal-weighted Fama-French-Carhart four-factor model returns over the 2-day window $[0,+1]$ surrounding the court decision estimated using equation (1). Each portfolio return represents an average two-day CAR and is calculated by multiplying the $\beta_{5}$ coefficient from Equation (1), which captures the average daily abnormal return during the event window, by two. The pre-event estimation period for the New York Supreme Court enforcement decision spans the 250 trading days between October 16, 2012 and October 11, 2013. The pre-event estimation period for the Illinois Chancery Court enforcement decision spans the 250 trading days between February 12, 2013 and February 11, 2014. The pre-event estimation period for the California Superior Court enforcement decision spans the 250 trading days between April 24, 2013 and April 23, 2014. There is a fifteen day gap between the end of the estimation windows and the event windows to avoid contamination from information leakage prior to the event. ${ }^{* * *},{ }^{* *}$, and ${ }^{*}$ denote statistical significance at the $1 \%, 5 \%$, and $10 \%$ levels respectively.

\begin{tabular}{lccc}
\hline \hline & \# of Firms & Portfolio CAR (\%) & t-stat \\
\hline New York Court (November 4, 2013) & 210 & $0.533 \%$ & $4.91^{* * *}$ \\
Illinois Court (March 5, 2014) & 127 & $0.393 \%$ & $5.21^{* * *}$ \\
California Court (May 14, 2014) & 503 & $0.167 \%$ & 0.84 \\
\hline \hline
\end{tabular}




\section{Table 7: Takeover Lawsuit Rates and Provision Adoption}

The table reports the rate of state-court class action litigation for a sample of firms that receive takeover offers. A sample of 83 exclusive forum provision adopters that receive a takeover offer are matched to a propensity score matched sample of 83 nonadopters. The propensity score model is based on the logit regression in Model 1 presented in Table 3. Panel A reports statistics related to all takeover-related lawsuit filings. Litigation Filed is an indicator equal to one if the takeover target was subject to a shareholder class action lawsuit in state court. Avg. Number of Lawsuits is the average number of class action lawsuits filed per takeover conditional on litigation being filed. Multiple Lawsuits is an indicator equal to one if the firm was subject to multiple state-court shareholder class action lawsuits conditional on litigation being filed. Avg. Number of Forums is the average number of forums that class action lawsuits are filed in per takeover conditional on litigation being filed. Multiple Forums is an indicator equal to one if the firm was subject to litigation in multiple forums conditional on litigation being filed. Filed in State of Incorp. is an indicator equal to one if the firm was subject to litigation in their state of incorporation (this includes firms in which their state of incorporation and state of headquarters are the same). Filed in State of HQ is an indicator equal to one if the firm was subject to litigation in their state of headquarters. Filed in State of Incorp. \& HQ is an indicator equal to one if the firm was subject to litigation in both their state of incorporation and state of headquarters. Federal Lawsuit Filed is an indicator equal to one if the firm was subject to litigation in a federal district court in conjunction with the takeover. Panel B (C) reports statistics related to the resolutions of takeover-related lawsuit filings (for exclusive forum provision adopters). Disclosure-only Settlement is an indicator equal to one if the takeover-related lawsuit settlement included only additional disclosure and payment of plaintiffs' attorneys' fees. Minor Adjustment Settlement is an indicator equal to one if the takeover-related lawsuit settlement included minor adjustments to the deal terms. Dismissed is an indicator equal to one if the takeover-related lawsuit was dismissed (either voluntarily or by the court) and did not result in any payment by defendants to plaintiffs. Column (1) reports the statistic for the matched non-adopting firms (inside the required forum), column (2) reports the statistic for adopting firms (outside the required forum), the third column reports the difference between columns (1) and (2), and the final column reports the two-tailed t-statistic for the difference in means. ${ }^{* * *},{ }^{* *}$, and ${ }^{*}$ denote statistical significance at the $1 \%, 5 \%$, and $10 \%$ levels respectively. 
Table 7: Takeover Lawsuit Rates and Provision Adoption (continued)

\begin{tabular}{|c|c|c|c|c|}
\hline Panel A: Lawsuit Filings & $\begin{array}{l}\text { Non-Adopters } \\
\qquad(1)\end{array}$ & $\begin{array}{r}\text { Adopters } \\
\text { (2) }\end{array}$ & $(2)-(1)$ & t-stat \\
\hline Number of Takeovers & 83 & 83 & & \\
\hline Number of Lawsuits Filed & 346 & 290 & & \\
\hline Litigation Filed (0/1) & $86.7 \%$ & $92.8 \%$ & $6.0 \%$ & 1.28 \\
\hline Avg. Number of Lawsuits & 4.75 & 3.74 & -1.05 & $1.74^{*}$ \\
\hline Multiple Lawsuits (0/1) & $79.2 \%$ & $79.2 \%$ & $0.6 \%$ & 0.01 \\
\hline Avg. Number of Forums & 1.47 & 1.22 & -0.25 & $3.33^{* * *}$ \\
\hline Multiple Forums (0/1) & $47.2 \%$ & $22.1 \%$ & $-25.1 \%$ & $3.33^{* * *}$ \\
\hline Filed in State of Incorp. (0/1) & $33.3 \%$ & $62.3 \%$ & $29.0 \%$ & $3.68^{* * *}$ \\
\hline Filed in State of HQ (0/1) & $18.1 \%$ & $14.3 \%$ & $-3.8 \%$ & 0.62 \\
\hline Filed in State of Incorp. \& HQ (0/1) & $45.8 \%$ & $22.1 \%$ & $-23.8 \%$ & $3.15^{* * *}$ \\
\hline Federal Lawsuit Filed (0/1) & $15.7 \%$ & $19.3 \%$ & $3.6 \%$ & 0.61 \\
\hline Panel B: All Lawsuit Resolutions & $\begin{array}{r}\text { Non-Adopters } \\
\qquad(1)\end{array}$ & $\begin{array}{r}\text { Adopters } \\
\text { (2) }\end{array}$ & $(2)-(1)$ & t-stat \\
\hline Disclosure-only Settlement (0/1) & $56.6 \%$ & $63.4 \%$ & $6.7 \%$ & $1.66^{*}$ \\
\hline Minor Adjustment Settlement (0/1) & $9.8 \%$ & $5.9 \%$ & $-3.9 \%$ & $1.77^{*}$ \\
\hline Dismissed (0/1) & $33.5 \%$ & $30.8 \%$ & $-2.8 \%$ & 0.72 \\
\hline \multirow[t]{2}{*}{$\begin{array}{c}\text { Panel C: Exclusive Forum Provision } \\
\text { Lawsuit Resolutions }\end{array}$} & $\begin{array}{l}\text { Inside } \\
\text { Required } \\
\text { Forum }\end{array}$ & $\begin{array}{r}\text { Outside } \\
\text { Required } \\
\text { Forum }\end{array}$ & $(2)-(1)$ & t-stat \\
\hline & (1) & (2) & & \\
\hline Disclosure-only Settlement (0/1) & $64.2 \%$ & $60.0 \%$ & $-4.2 \%$ & 0.58 \\
\hline Minor Adjustment Settlement (0/1) & $5.5 \%$ & $7.3 \%$ & $1.8 \%$ & 1.15 \\
\hline Dismissed (0/1) & $30.3 \%$ & $32.7 \%$ & $2.5 \%$ & 0.49 \\
\hline
\end{tabular}




\section{Table 8: Non-Takeover Derivative and Class Action Lawsuit Rates and Provision Adoption}

The table reports the rate of non-takeover derivative and class action litigation filed in state courts for a sample of exclusive forum provision adopters and a matched sample of non-adopting firms. Non-adopting firms are matched based on year, industry, and a propensity score model following the logit regressions presented in Table 3. Panel A reports the annual rate of litigation for the adopter and the matched non-adopter samples for up to three years following adoption. The adopter firm sample includes 495 firms and 890 firm-years. The non-adopter sample includes 1,033 firms and 2,730 firm-years. Litigation Filed is an indicator equal to one if the firm was subject to non-takeover related shareholder derivative or class action litigation in a given firm-year. Multiple Lawsuits is an indicator equal to one if the firm was subject to multiple non-takeover related shareholder derivative or class action lawsuits in a given firm-year. Multiple Forum is an indicator equal to one if the firm was subject to non-takeover related shareholder derivative or class action lawsuits in multiple states in a given firm-year. Dismissed Litigation is an indicator equal to one if the firm was subject to non-takeover related shareholder derivative or class action litigation that was dismissed in a given firm-year and did not result in any payment by defendants to plaintiffs. Federal Litigation Filed is an indicator equal to one if the firm was subject to shareholder derivative litigation that was filed in federal court in a given firm-year. Panel B reports litigation characteristics for any lawsuits filed following adoption for the adopter and non-adopter samples. Column (1) reports the statistic for the matched non-adopting firms, column (2) reports the statistic for adopting firms, the third column reports the difference between columns (1) and (2), and the final column reports the two-tailed t-statistic for the difference in means. ${ }^{* * *},{ }^{* *}$, and ${ }^{*}$ denote statistical significance at the $1 \%, 5 \%$, and $10 \%$ levels respectively.

Panel A: Rate of Litigation - Post-Adoption

\begin{tabular}{lrrrr}
\hline & Non-Adopters & Adopters & $(2)-(1)$ & t-stat \\
& 2,730 & $(1)$ & & \\
\hline Number of Firm-Years & $2.75 \%$ & $3.48 \%$ & $0.74 \%$ & 1.13 \\
Litigation Filed & $1.17 \%$ & $1.12 \%$ & $-0.05 \%$ & 0.12 \\
Multiple Lawsuits & $0.29 \%$ & $0.00 \%$ & $-0.29 \%$ & $2.83^{* * *}$ \\
Multiple Forums & $1.21 \%$ & $0.56 \%$ & $-0.65 \%$ & $1.98^{* *}$ \\
Dismissed Litigation & $1.61 \%$ & $0.79 \%$ & $-0.82 \%$ & $2.16^{* *}$ \\
Federal Litigation Filed & & & & \\
\hline Panel B: Filed Litigation - Post-Adoption & & & \\
\hline & Non-Adopters & Adopters & $(2)-(1)$ & t-stat \\
& $(1)$ & $(2)$ & & \\
\hline Number of Lawsuits & 118 & 54 & & \\
Number of Derivative Suits & 104 & 46 & & \\
Number of Class Action Suits & 14 & $8.86^{* * *}$ \\
Multiple Lawsuits & $39.4 \%$ & $32.4 \%$ & $-7.0 \%$ & 0.69 \\
Multiple Forums & $7.6 \%$ & $0.00 \%$ & $-7.6 \%$ & $2.31^{* *}$ \\
Dismissed Litigation & $39.4 \%$ & $14.7 \%$ & $-24.7 \%$ & \\
\hline \hline
\end{tabular}




\section{Table 9: Takeover Premiums and Provision Adoption}

The table reports regressions modeling takeover premiums around takeover announcements as a function of exclusive forum provision adoption. The sample consists of 1,011 takeovers of sample firms from 2009-2015. The sample includes 100 takeovers of adopting firms and 911 takeovers of non-adopting firms. The first stage OLS model used to instrument for provision adopter is presented in Model 1. The dependent variable is an indicator equal to one if the firm has an exclusive forum provision, zero otherwise. The instrument is Delaware Inc. which is an indicator equal to one if a firm is incorporated in Delaware. The fitted value from this regression is used as the main variable of interest (Provision Adopter) in Models 2-5. In the second stage Models 2-5, the dependent variable is a measure of merger premium. The dependent variable in Model 2 is the target Fama-French-Carhart four-factor adjusted cumulative abnormal return over the $[-1,+1]$ window surrounding the takeover announcement. The dependent variable in Model 3 is the target Fama-French-Carhart four-factor adjusted cumulative abnormal return over the [-2, +2] window surrounding the takeover announcement. The dependent variable in Model 4 is the target Fama-French-Carhart four-factor adjusted cumulative abnormal return over the $[-5,+5]$ window surrounding the takeover announcement. The dependent variable in Model 5 is the target Fama-French-Carhart four-factor adjusted cumulative abnormal return over the $[-42,+30]$ window surrounding the takeover announcement. Firm Size is the natural log of total market capitalization. Stock Return is the one-year buy and hold abnormal return over the prior fiscal year. FCF is operating cash flow minus dividends scaled by total book value of assets. Leverage is total book value of debt scaled by total book value of assets. Market-to-book is the ratio of the market value of equity to book value of equity. All of these independent variables are measured at the end of the fiscal year prior to the takeover announcement. Public Acquirer is an indicator equal to one if the acquirer is a publicly traded company. Acquirer EFP is an indicator equal to one if the acquirer has an exclusive forum provision. Unsolicited is an indicator equal to one if the takeover is an unsolicited offer as defined by SDC. Cash is an indicator equal to one if the bid involved a payment of cash (even if mixed with other securities) to target shareholders. Tender Offer is an indicator equal to one if the bid is a tender offer to target shareholders. Same Industry is an indicator equal to one if the acquirer and target are in the same Fama-French 12 industry classification. Acquirer Term. Fee is an indicator equal to one if the there is an acquirer termination fee. Target Term. Fee is an indicator equal to one if the there is a target termination fee. Year and industry fixed effects based on Fama-French 12 industry classifications are also included in all models. $p$-values based on standard errors clustered by Fama-French 12 industry classification are in parentheses. ${ }^{* * *},{ }^{* *}$, and ${ }^{*}$ denote statistical significance at the $1 \%, 5 \%$, and $10 \%$ levels respectively. 
Table 9: Takeover Premiums and Provision Adoption (continued)

\begin{tabular}{|c|c|c|c|c|c|}
\hline & \multirow{2}{*}{$\begin{array}{c}\text { First Stage } \\
\text { Model } 1\end{array}$} & \multicolumn{4}{|c|}{ Second Stage } \\
\hline & & Model 2 & Model 3 & Model 4 & Model 5 \\
\hline & $\begin{array}{c}\text { Provision } \\
\text { Adopter }\end{array}$ & $\begin{array}{c}\text { Target } \\
\text { Premium: } \\
\text { CAR }[-1,+1]\end{array}$ & $\begin{array}{c}\text { Target } \\
\text { Premium: } \\
\text { CAR }[-2,+2]\end{array}$ & $\begin{array}{c}\text { Target } \\
\text { Premium: } \\
\text { CAR }[-5,+5]\end{array}$ & $\begin{array}{c}\text { Target } \\
\text { Premium: } \\
\text { CAR }[-42,+30]\end{array}$ \\
\hline Intercept & $\begin{array}{c}-0.138^{* *} \\
(0.023)\end{array}$ & $\begin{array}{c}0.398^{* * *} \\
(0.000)\end{array}$ & $\begin{array}{l}0.407^{* * *} \\
(0.000)\end{array}$ & $\begin{array}{c}0.452^{* * *} \\
(0.000)\end{array}$ & $\begin{array}{c}0.373^{* * *} \\
(0.000)\end{array}$ \\
\hline Provision Adopter & & $\begin{array}{l}0.436^{* * *} \\
(0.005)\end{array}$ & $\begin{array}{l}0.431^{* * *} \\
(0.006)\end{array}$ & $\begin{array}{l}0.354^{* *} \\
(0.022)\end{array}$ & $\begin{array}{l}0.480^{* *} \\
(0.033)\end{array}$ \\
\hline Delaware Inc. & $\begin{array}{l}0.082^{* * *} \\
(0.002)\end{array}$ & & & & \\
\hline Firm Size & $\begin{array}{c}0.008 \\
(0.345)\end{array}$ & $\begin{array}{c}-0.038^{* * *} \\
(0.000)\end{array}$ & $\begin{array}{c}-0.038^{* * *} \\
(0.000)\end{array}$ & $\begin{array}{c}-0.038^{* * *} \\
(0.000)\end{array}$ & $\begin{array}{c}-0.041^{* * *} \\
(0.000)\end{array}$ \\
\hline Stock Return & $\begin{array}{l}-0.015 \\
(0.149)\end{array}$ & $\begin{array}{l}-0.010 \\
(0.625)\end{array}$ & $\begin{array}{l}-0.011 \\
(0.563)\end{array}$ & $\begin{array}{l}-0.017 \\
(0.397)\end{array}$ & $\begin{array}{c}-0.118^{* * *} \\
(0.000)\end{array}$ \\
\hline FCF & $\begin{array}{c}0.034 \\
(0.451)\end{array}$ & $\begin{array}{l}-0.035 \\
(0.706)\end{array}$ & $\begin{array}{l}-0.034 \\
(0.699)\end{array}$ & $\begin{array}{l}-0.035 \\
(0.708)\end{array}$ & $\begin{array}{l}-0.083 \\
(0.308)\end{array}$ \\
\hline Leverage & $\begin{array}{c}-0.002 \\
(0.965)\end{array}$ & $\begin{array}{c}0.023 \\
(0.592)\end{array}$ & $\begin{array}{c}0.026 \\
(0.548)\end{array}$ & $\begin{array}{c}0.028 \\
(0.505)\end{array}$ & $\begin{array}{l}0.129^{* *} \\
(0.016)\end{array}$ \\
\hline Market-to-book & $\begin{array}{l}0.006^{* *} \\
(0.019)\end{array}$ & $\begin{array}{l}-0.004^{* *} \\
(0.039)\end{array}$ & $\begin{array}{l}-0.004^{*} \\
(0.057)\end{array}$ & $\begin{array}{l}-0.003 \\
(0.124)\end{array}$ & $\begin{array}{l}-0.005^{*} \\
(0.054)\end{array}$ \\
\hline Public Acquirer & $\begin{array}{c}-0.028 \\
(0.244)\end{array}$ & $\begin{array}{l}0.037^{* *} \\
(0.011)\end{array}$ & $\begin{array}{l}0.037^{* *} \\
(0.019)\end{array}$ & $\begin{array}{c}0.031^{*} \\
(0.053)\end{array}$ & $\begin{array}{c}0.064^{*} \\
(0.079)\end{array}$ \\
\hline Acquirer EFP & $\begin{array}{c}0.032 \\
(0.246)\end{array}$ & $\begin{array}{l}-0.022 \\
(0.408)\end{array}$ & $\begin{array}{l}-0.023 \\
(0.491)\end{array}$ & $\begin{array}{l}-0.018 \\
(0.555)\end{array}$ & $\begin{array}{l}-0.032 \\
(0.517)\end{array}$ \\
\hline Unsolicited & $\begin{array}{c}0.053 \\
(0.252)\end{array}$ & $\begin{array}{l}-0.049 \\
(0.126)\end{array}$ & $\begin{array}{l}-0.046 \\
(0.174)\end{array}$ & $\begin{array}{l}-0.035 \\
(0.251)\end{array}$ & $\begin{array}{l}-0.028 \\
(0.436)\end{array}$ \\
\hline Cash & $\begin{array}{c}0.004 \\
(0.841)\end{array}$ & $\begin{array}{l}0.108^{* * *} \\
(0.000)\end{array}$ & $\begin{array}{l}0.107^{* * *} \\
(0.000)\end{array}$ & $\begin{array}{c}0.098^{* * *} \\
(0.001)\end{array}$ & $\begin{array}{l}0.123^{* * *} \\
(0.000)\end{array}$ \\
\hline Tender Offer & $\begin{array}{c}0.014 \\
(0.525)\end{array}$ & $\begin{array}{l}-0.010 \\
(0.686)\end{array}$ & $\begin{array}{l}-0.010 \\
(0.692)\end{array}$ & $\begin{array}{l}-0.011 \\
(0.640)\end{array}$ & $\begin{array}{c}0.017 \\
(0.570)\end{array}$ \\
\hline Same Industry & $\begin{array}{l}-0.026 \\
(0.132)\end{array}$ & $\begin{array}{c}0.038^{*} \\
(0.072)\end{array}$ & $\begin{array}{c}0.039^{*} \\
(0.098)\end{array}$ & $\begin{array}{c}0.035 \\
(0.146)\end{array}$ & $\begin{array}{c}0.027 \\
(0.180)\end{array}$ \\
\hline Acquirer Term. Fee & $\begin{array}{l}-0.011 \\
(0.704)\end{array}$ & $\begin{array}{c}-0.045^{* * *} \\
(0.003)\end{array}$ & $\begin{array}{c}-0.044^{* * *} \\
(0.005)\end{array}$ & $\begin{array}{c}-0.050^{* * *} \\
(0.002)\end{array}$ & $\begin{array}{l}-0.032 \\
(0.104)\end{array}$ \\
\hline Target Term. Fee & $\begin{array}{c}0.045 \\
(0.112)\end{array}$ & $\begin{array}{c}0.035 \\
(0.296)\end{array}$ & $\begin{array}{c}0.039 \\
(0.218)\end{array}$ & $\begin{array}{c}0.039 \\
(0.234)\end{array}$ & $\begin{array}{c}0.053 \\
(0.195)\end{array}$ \\
\hline $\begin{array}{l}\text { Year \& Industry } \\
\text { Fixed Effects }\end{array}$ & Yes & Yes & Yes & Yes & Yes \\
\hline Observations & 1,011 & 1,011 & 1,011 & 1,011 & 1,011 \\
\hline Adjusted $r^{2}$ & 0.267 & 0.127 & 0.121 & 0.123 & 0.151 \\
\hline
\end{tabular}

